
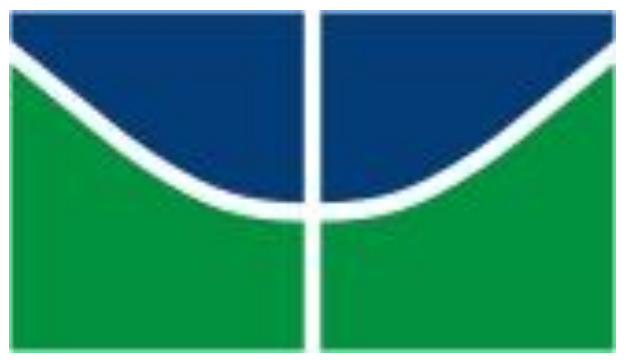

Universidade de Brasília Instituto de Ciências Biológicas

Departamento de Botânica

Programa de Pós-graduação em Botânica

\title{
EXPRESSÃO DO GENE DA ESFINGOMIELINASE DE Trichoderma EM TABACO (Nicotiana tabacum L.)
}

\section{PEDRO SOUZA BERBERT}

\author{
Brasília-DF
}




\title{
EXPRESSÃO DO GENE DA ESFINGOMIELINASE DE Trichoderma EM
}

TABACO (Nicotiana tabacum L.)

\begin{abstract}
Dissertação apresentada ao
Departamento de Botânica, do Programa

de Pós-graduação em Botânica, da

Universidade de Brasília, como parte dos

requisitos necessários à obtenção do título de Mestre em Botânica.
\end{abstract}

PEDRO SOUZA BERBERT

Orientador: Prof. Dr. Francisco José Lima Aragão

Brasília- DF

2015 


\title{
EXPRESSÃO DO GENE DA ESFINGOMIELINASE DE Trichoderma EM TABACO (Nicotiana tabacum L.)
}

\author{
PEDRO SOUZA BERBERT
}

\author{
Banca Examinadora
}

Dr. Francisco José Lima Aragão - Orientador

Dr. Thomas Christopher Rhys Williams

Dr. Cirano José Ulhoa

Dra. Pabline Marinho Vieira 


\section{DEDICATÓRIA}

Dedico este trabalho aos meus pais

Paulo e Regina, à minha família, aos amigos e todos aqueles que sempre me apoiaram e incentivaram chegar até aqui. 


\section{AGRADECIMENTOS}

Uma das mais difíceis tarefas é agradecer todos aqueles que fizeram parte desta jornada. Agradeço aos meus pais, Paulo e Regina, pela educação, amor e ajuda que me deram em todos os momentos da minha vida.

Ao meu irmão André, pelo companheirismo e exemplo de pessoa por quem sempre tive respeito e consideração.

À minha família, aos meus avós, aos meus tios pelo apoio e carinho.

Agradeço a Lídia, pelo amor, pelo incentivo e paciência.

Agradeço ao meu Orientador, Francisco José Lima Aragão, pela oportunidade, pela orientação, pelo conhecimento transmitido e apoio incondicional.

Agradeço ao Sérgio Araújo Figueiredo, pela oportunidade de conhecer o Laboratório de Transferência Genética, pelos minuciosos ensinamentos e pelo exemplo de competência.

Agradeço à Gláucia Cabral, pela orientação extra oficial deste trabalho, pelas inúmeras sugestões, e apoio dispensado em diversas oportunidades.

Agradeço a Elsa Nogueira pela disponibilidade, paciência, pelos ensinamentos e conhecimentos compartilhados.

Agradeço a Pabline, pela oportunidade e pelos ensinamentos.

Aos meus amigos de laboratório pelo companheirismo, amizade e ajuda: Abdul, Aline, Ana Zotta, Angélica, Carolzinha, Cristiana Andrade, Cristiane Citadin, Cristina, Filipe, Henrique, Heitor, Leonardo, Maria Laine, Mirella, Natália, Nayanne, Otacílio, Pabline, Rebecca, Robertinho, Tati, Thainá, Thais, Tomas e aos que também passaram por aqui. Aos colegas da Cultura de Tecidos Hugo, Patrícia, André, Zan, Gaby e Filipe e Paulo, pelos ensinamentos, pela amizade e ajuda dispensada. 
Agradeço os professores da Botânica, em especial aos da Fisiologia Vegetal: Augusto César Franco, Cristiane Ferreira, Thomas Willians pelos ensinamentos e oportunidades concedidas, os amigos Fabio Nakamura, Aline Clawdy, Isa e JéssikaVieira pelos momentos de convivência e aprendizado.

A Dr. Joseane pelo apoio nas análises estatísticas e pelo exemplo bondade.

Agradeço aos membros da banca que contribuíram com preciosas sugestões para o meu trabalho.

Agradeço a CAPES pela bolsa concedida, e à EMBRAPA pela estrutura física fornecida. 


\section{RESUMO}

Doenças de plantas causadas por fungos patogênicos estão entre os principais fatores responsáveis por perdas agrícolas no país. Os estudos sobre controle biológico representam abordagem importante no controle de tais doenças. Entre os microrganismos mais utilizados está o fungo pertencente ao gênero Trichoderma e uma estratégia chave envolve a identificação e expressão dos genes de Trichoderma para permitir a sua utilização como ferramenta biotecnológica no controle de doenças de plantas. Foi demonstrado que o gene que codifica para a esfingomielinase é expresso contra o fungo Fusarium. O objetivo deste trabalho foi o de gerar plantas de Nicotiana tabacum para expressar o gene de uma esfingomielinase de Trichoderma e avaliar resistência a fitopatógenos. Plantas de tabaco foram transformadas via Agrobacterium tumefaciens com um vetor contendo o gene da esfingomielinase sob o controle do promotor constitutivo CaMV35S. Um total de vinte e sete plantas foram geradas. Sementes de 10 linhagens $T_{1}$ foram plantadas em casa de vegetação e 5 indivíduos por linhagem foram selecionados através da aplicação do herbicida glifosinato a uma concentração de $200 \mathrm{mg} / \mathrm{mL}$. As plantas que não apresentaram nenhuma lesão foram confirmadas para a presença do gene esfingomielinase através de PCR, e, em seguida, utilizadas nos bioensaio. Os Bioensaios para testar resistência ao fungo Sclerotinia scletotiorum mostrou que as linhagens transgênicas não diferiram significativamente do controle. No entanto, quando as plantas foram desafiadas com a bactéria Pseudomonas syringae pv. tabaci, observou-se uma notável diferença entre os transgênicos e o controle. Este estudo deve formar a base para o desenvolvimento de uma estratégia para controle de doenças bacterianas em plantas.

Palavra chave: Transformação genética, Controle biológico, Fitopatógenos, Resistência. 


\begin{abstract}
Plant diseases caused by pathogenic fungus are among the major factors responsible for agricultural losses in the country. Studies on biological control represent important approach in controlling these diseases. Among the most commonly used microorganisms used is the fungus belonging to the Trichoderma genera and a key strategy entails the identification and expression of genes in Trichoderma to allow for their use as biotechnological tools in controlling plant diseases. It has been demonstrated that the gene coding for sphingomylinase is expressed against the pathogen Fusarium. The objective of this work was to generate Nicotiana tabacum plants express the gene for sphingomylinase from Trichoderma and test the plants for resistance against the pathogen. Tobacco plants were transformed (with the gene for sphingomylinase under the control of the constitutive promoter CaMV35S) via Agrobacterium tumefaciens. Twenty-seven plants were generated. Seeds from $10 \mathrm{~T}_{1}$ lines were planted in greenhouse and 5 individuals per line were selected and treated by applying the herbicide glyphosinate at a concentration of $200 \mathrm{mg} / \mathrm{mL}$. Bioassay to test resistance against the fungus Sclerotinia scletotiorum was carried out and showed that transgenic lines did not significantly differ from the control. However, when the plants were challenged with the bacteria Pseudomonas syringae pv. tabaci, showed remarkable difference between transgenic and non-transgenic lines. This study shall form the basis for developing a strategy for controlling fungal diseases in plants using biological means.
\end{abstract}

Keywords: Genetic Transformation, Biological Control, Plant Pathogens, Resistance 


\section{LISTA DE FIGURA E TABELA}

Figura 1: Estrutura geral dos esfingolipídeos de membrana (NELSON \& COX, 2011)

Tabela 1: Análise da segregação das linhagens geneticamente modificadas através da seleção das plantas positivas pela aplicação do herbicida glifosinato de amônio e pela aplicação do teste Qui-Quadrado com correção de Yates que calcula a probabilidade de ocorrência de uma ou duas cópias do transgene no genoma. $\chi 2$ : Qui-Quadrado, P: Probabilidade. .25

Figura 2: Representação gráfica da atividade da esfingomielinase ácida liberando fosforil colina e ceramida (KING, 2014). 8

Figura 3: Representação esquemática do vetor pC3300GCHI.Sphingo contendo o promotor CaMV35S dirigindo a expressão do gene da esfingomielinase com o terminador TNOS, o gene de resistência para planta bar, e o gene nptI que confere resistência a canamicina. .21

Figura 4: Gel de agarose (1\%) mostrando a digestão do vetor pC3300GCHI-Sphingo com as enzimas Nco I/Sac I e EcoR I Poço1: marcador de massa molecular 1kb Ladder (Invitrogen), Poço 2: clone 1 negativo de E. coli digerido com enzimas Nco I/Sac I, Poço 3: clone 2 positivo de E. coli digerido com enzimas Nco I/Sac I, Poço 4: clone 3 positivo de E. coli digerido com enzimas Nco I/Sac I, Poço 5: clone 4 de E. coli digerido com enzimas Nco I/Sac I, Poço 6: clone de E. coli digerido com enzimas Nco I/Sac I. Poço 8: clone 1 negativo de E. coli digerido com enzima EcoR I, Poço 9: clone 2 positivo de E. coli digerido com enzima EcoR I, Poço 10: clone 3 positivo de E. coli digerido com enzima EcoR I.

Figura 5: Gel de agarose (1\%) da análise por PCR dos clones transformantes. Poço1: marcador de massa molecular $1 \mathrm{~kb}$ Ladder (Invitrogen), poço 2: controle positivo, poço 3: controle negativo, poço 4-5: clone de E. coli, poço 6-9 clones positivos de Agrobacterium. .22

Figura 6. Regeneração de explantes foliares de tabaco após a transformação por Agrobacterium tumefaciens. (A) Explantes um mês após a cocultura com início de regeneração de gemas adventícias, (B) multiplicação de gemas adventícias, (C) elongação de brotos na presença do agente seletivo GA $5 \mathrm{mg} / \mathrm{L} \mathrm{e} \mathrm{(D)} \mathrm{broto} \mathrm{isolado} \mathrm{em}$ elongação na presença do herbicida GA, (E) brotos elongados transferidos para meio de enraizamento e (F) Plântula de fumo três meses após a transformação genética.

Figura 7. Teste de cromatografia de fluxo lateral realizado com extrato de folhas de tabaco regeneradas na presença do herbicida GA para detecção da proteína PAT. (1) Planta transgênica, a linha inferior denota a presença da proteína PAT. (2) Controle 
negativo, folha de tabaco não transformado, apenas a linha do controle negativo foi observada.

Figura 8: Teste com aplicação do herbicida glifosinato para seleção de progênies transgênicas T1: (8.A) Plantas resistentes ao herbicida não apresentaram lesões, enquanto em (8.B) podemos observar sintomas de necrose na planta susceptível ao herbicida. .24

Figura 9: Gel de agarose (2\%) do PCR de cinco plantas (números de 1 a 5) das 15 plantas T1 testadas de cada linhagem de Tabaco transformadas com o vetor pC3300GCHI.Sphingo utilizadas nos bioensaios, $\mathrm{Sph}=$ Sphingo, seguido do número da linhagem. MM 100 pb: marcador de massa molecular 100 bp Ladder (Invitrogen); Sph.1 a Sph.12: Linhagem (1) onde os números de 1 a 5 refere-se ao DNA extraído de 5 progênies de cada linhagem. $\mathrm{H}_{2} 0$ : Água, $\mathrm{C}$-: Planta não transformada, $\mathrm{C}+1$ : Clone de $E$. coli com o vetor Pc3300.Sphingo, C+.2: vetor Pc3300.Sphingo. 26

Figura 10: Curva de progresso da doença obtida a partir da média das áreas lesionadas na duas repetições após a inoculação de folhas destacadas com discos de micélio do fungo S. sclerotiorum. A área infectada foi medida em milímetros 48 e 72 horas após a inoculação.

Figura 11 - Resposta de folhas destacadas a S. sclerotiorum obtida pela inoculação com discos de micélio. 1) Folhas do evento Sphingo 1 não transgênico após 48 horas(A) e 72 horas (B) ; 5) Folhas do evento Sphingo 5 transgênico após 48(C), 72(D); 6) Folhas do evento Sphingo 6 transgênico após 48(E), 72(F); 10) Folhas do evento Sphingo 10 transgênico após 48(G), 72(H); C -) Folhas do controle negativo após 48(I), 72(J).......28

Figura 12: Área afetada nas três repetições experimentais. Letras iguais mostram que as repetições são iguais segundo o teste não paramétrico de (Kruskal-Wallis $=116,1609$, p-valor $<0,001)$

Figura 13: Análise de variância utilizando o teste ANOVA não paramétrico entre as repetições. Letras iguais mostram que as repetições são iguais segundo o teste não paramétrico de $($ Kruskal-Wallis $=0,6143$, p-valor $<0,43)$. 30

Figura 14. Área afetada das linhagens amostradas nas repetições experimentais. Letras iguais mostram que as linhagens são iguais segundo o teste não paramétrico de (Kruskal-Wallis $=13.11$, $\mathrm{p}$-valor $<0.21$ ). 30

Figura 15. Distribuição em grupo das linhagens na ordem decrescente das médias. Letras/Cores iguais mostram que as repetições são iguais segundo o teste ScottKnott à $5 \%$ de significância 31

Figura 16: Bioensaio com a bactéria Pseudomonas pv. tabaci. Resposta de folhas destacadas a infiltração da suspensão bacteriana após 7 e 14 dias de infiltração. 1) Folha do evento Sphingo 1 não transgênico; C -) Folhas do controle negativo; 2-12 Folhas dos eventos transgênicos após 7 e 14 dias de infiltração. 
Figura 17: Gráfico das áreas lesionadas nas duas repetições após a inoculação de folhas destacadas com a bactéria $P$. syringae. A,B: Curva de progresso da doença obtida a partir da média das progênies. C:D: Gráfico em barras com os valores médios de área infiltrada obtidos para cada linhagem.

Figura 18: Média das áreas lesionadas obtidas com a infiltração de Pseudomonas syringae nas duas repetições. As letras iguais mostram que as repetições são iguais segundo o teste não paramétrico de Kruskal-Wallis $=2.978$, p-valor $=0,084) \ldots \ldots \ldots \ldots \ldots . . .34$

Figura 19: Média das áreas lesionadas obtidas com a infiltração de Pseudomonas syringae para cada linhagem. As letras iguais mostram que as repetições são iguais segundo o teste não paramétrico de Kruskal-Wallis $=222,42$ p-valor $<0,001 \ldots \ldots \ldots \ldots . . . .34$

Figura 20. Distribuição em grupos das linhagens amostradas nas repetições experimentais. Cores iguais mostram que as repetições são iguais segundo o teste

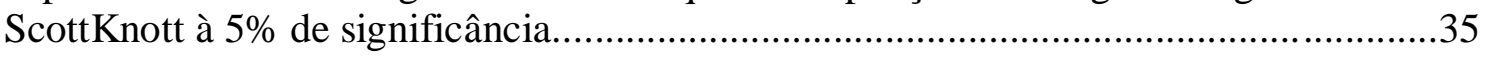

Figura 21: Perdas de clorofila que ocorrem naturalmente nas folhas das linhagens após 14 dias de ensaio.

Figura 22. Gráfico das porcentagens de perdas de clorofila nas regiões infiltradas com a bactéria $P$. syringae. A: Perdas de clorofila das linhagens na primeira repetição de infiltração de P. syringae, B: A: Perdas de clorofila das linhagens na segunda repetição de infiltração de P. syringae. .35

Figura 23: Meios de cultivo semi seletivos MSP e SPA contendo colônias de Pseudomonas syringae recuperada das folhas infiltradas no bioensaio 


\section{SUMÁRIO}

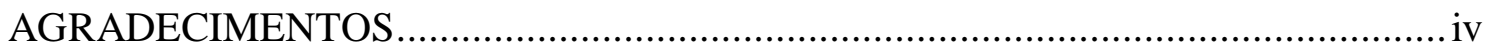

RESUMO …

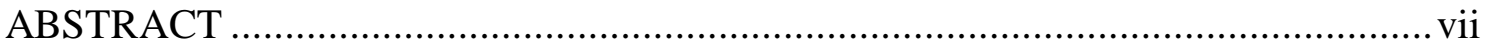

LISTA DE FIGURA E TABELA......................................................................... viii

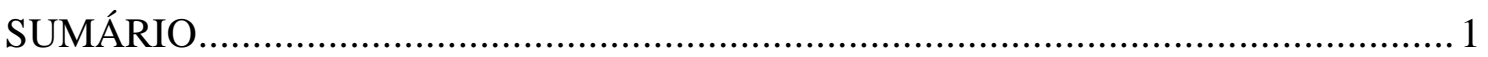

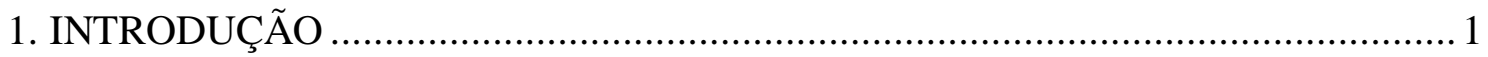

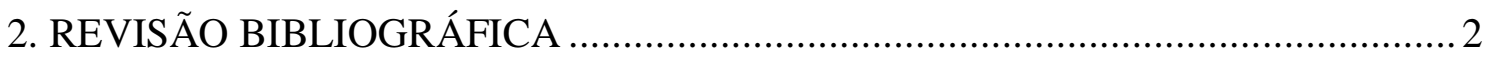

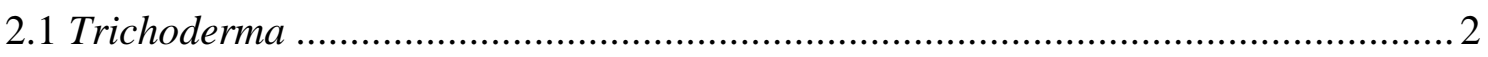

2.2. O estudo do biocontrole de Trichoderma ……………..................................... 4

2.3 Desestabilizando a membrana, uma forma de desenvolvimento de terapias antimicrobiana e antifúngica. .................................................................................

2.4 Transformação genética de plantas utilizando genes de Trichoderma .....................10

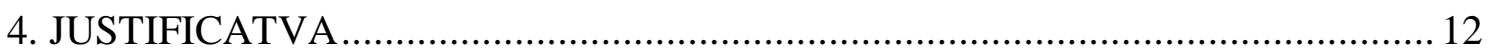

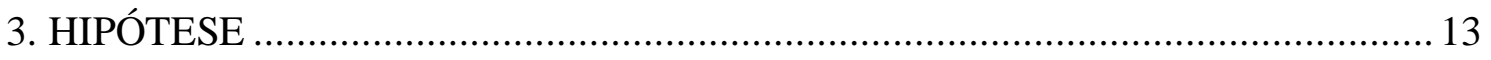

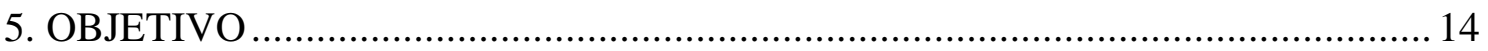

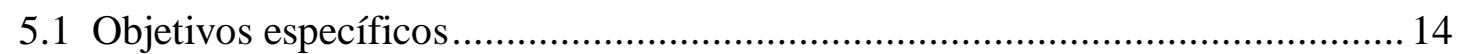

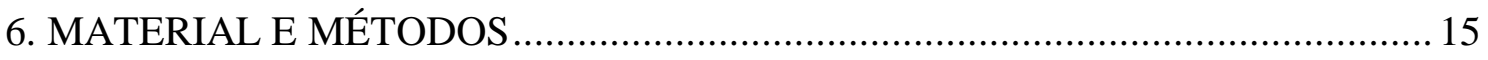

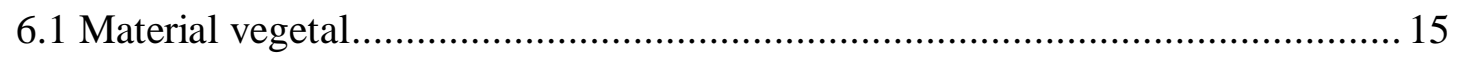

6.2 Construção do vetor de expressão contendo o gene de esfingomielinase ............. 15

6.3 Transformação de E. coli por eletroporação e extração de DNA plasmidial (Miniprep) ................................................................................................ 15 
6.5 Transformação genética de plantas de tabaco

6.6 Análise das plantas regeneradas

6.6.1 PCR para detecção do gene esfingomielinase.

6.6.2 Teste para detecção da proteína PAT

6.6.3 Análise da segregação das $\mathrm{T}_{1}$

6.7 Bioensaios

6.8 Produção do inoculo de fungo

6.9 Teste das folhas destacadas.

6.10 Infiltração com Pseudomonas syringae pv. tabaci

6.11 Recuperação de $P$. syringae pv tabaci das regiões infiltradas.

6.12 Análises estatísticas

7. RESULTADOS

7.1.1 Construção do vetor contendo o gene da esfingomielinase

7.1.2 Análise por PCR dos clones de E. coli e Agrobacterium. 22

7.1.3 Transformação genética de plantas de tabaco com o vetor pC3300GCHI.Sphingo

7.2.1 Análise da segregação e seleção de plantas $T_{1}$

7.2.2 Desafio de Folhas destacadas utilizando discos de micélio de S. Scletoriorum 26

7.2.3. Infiltração com Pseudomonas syringae pv. tabaci

7.2.3.2. Recuperação e identificação das bactérias 
DISCUSSÃO

CONCLUSÃO

PERSPECTIVAS

REFERÊNCIAS BIBLIOGRÁFICAS

44 


\section{INTRODUÇÃO}

As doenças de plantas constituem um dos principais fatores responsáveis por perdas na produção agrícola do país, sendo os fungos os principais agentes patogênicos; dentre as doenças mais importantes encontram-se fungos de espécies dos gêneros Fusarium, Pythium, Rhizoctonia, Macrophomina, Sclerotina, Botrytis e Crinipellis, que afetam várias culturas como feijão, soja, algodão, fumo, morango, tomate, cebola, alho, cacau e plantas ornamentais (BETTIOL \& MORANDI, 2009).

O controle biológico de pragas é uma abordagem importante baseada no uso de organismos específicos para controlar patógenos, podendo ser uma alternativa ao controle químico de fitopatógenos, ou ainda um aliado deste no manejo integrado de pragas. Dentre os estudos de controle biológico utilizando microrganismos destaca-se o uso de fungos de solo Trichoderma spp, os mais estudados como antagonistas de fitopatógenos (BENÍTEZ et al., 2004). Devido à essa atividade do Trichoderma vários estudos objetivaram conhecer os mecanismos envolvidos no controle biológico, que vão desde a competição por nutrientes e espaço, antibiose através da produção de metabólitos inibidores, micoparasitismo do fitopatógeno até a indução de mecanismos de defesa nas plantas (HOWELL, 2003).

A busca por plantas resistentes a fungos tem levado pesquisadores à identificação de genes de Trichoderma com reconhecido interesse biotecnológico. Estudos moleculares dos mecanismos envolvidos no controle biológico são necessários para compreender o processo e para viabilizar a utilização de proteínas ou genes específicos de Trichoderma (KUBICEK et al., 2011; LORITO et al., 2010; VINALE et al., 2008). O silenciamento e/ou a superexpressão são ferramentas poderosas para a determinação da função dos genes envolvidos no biocontrole pela engenharia genética de fungos e plantas (ISLAM, 2006).

As análises de ESTs (Expressed Sequence Tags) têm sido utilizadas em diversos trabalhos para identificar genes de Trichoderma diferencialmente expressos em várias condições de cultivo e também durante a interação com fitopatógenos e plantas (LIU \& YANG, 2005; STEINDORFF et al., 2012; VIEIRA et al., 2013). A hibridização 
subtrativa (suppression subtractive hybridization - SSH) é um método usado para isolar e clonar genes diferencialmente expressos entre duas populações de cDNA, sintetizados a partir de mRNAs obtidos em condições distintas (REBRIKOV et al., 2008)

Neste contexto, a identificação de genes de Trichoderma e a introdução e expressão desses genes é uma ferramenta biotecnológica importante para o controle de doenças de plantas. Com a expressão de um gene de esfingomielinase de Trichoderma virens em plantas de Nicotiana tabacum, surge uma possível estratégia para geração de plantas resistentes a fungos e bactérias.

\section{REVISÃO BIBLIOGRÁFICA}

\subsection{Trichoderma}

O Gênero Trichoderma descrito por Persoon em 1794 pertence ao Reino Fungi, Filo Ascomycota, Classe Ascomycetes, Ordem Hypocreales e Família Hypocreaceae (KIRK, 2014). Esse gênero compreende espécies de fungos filamentosos saprófitas com dois estágios morfológicos e fisiológicos diferentes. O estágio sexual (telemorfo) conhecido é denominado Hypocrea, enquanto que a fase assexuada (anamorfa) é chamada Trichoderma. Os fungos possuem ampla gama de pigmentos e um conjunto de características morfológicas comuns, e análises moleculares têm sido utilizadas nos estudos de filogenia e na diferenciação de espécies (HERMOSA et al., 2000; SCHUSTER \& SCHMOLL, 2010).

Trichoderma spp. são encontrados amplamente distribuídas por todo o mundo, onde vivem no solo e em uma grande variedade de ecossistemas, sendo capazes de crescer em inúmeros substratos, tais como madeira, troncos em decomposição e inclusive sobre outros fungos (BROTMAN, 2010; KLEIN, 1998). A capacidade de secretar enzimas e antibióticos permite a sobrevivência em inúmeros substratos (SCHUSTER \& SCHMOLL, 2010). Sua elevada taxa de reprodução, a capacidade de sobreviver sob condições desfavoráveis, a eficiência na utilização de nutrientes, a capacidade de modificar a rizosfera, o antagonismo contra fungos fitopatogênicos e a promoção dos mecanismos de defesa e crescimento das plantas são características das espécies de Trichoderma (BENITEZ et al, 2004). 
Espécies do gênero Trichoderma são amplamente conhecidas devido à sua utilização como Agentes de Controle Biológico (BCA) e sua capacidade de antagonizar fitopatógenos habitantes de solo, por uma combinação de vários mecanismos como competição, antibiose e micoparasitismo (BROTMAN et al., 2010; VINALE et al., 2008). A competição é descrita por Odum (1986) como uma interação que afeta adversamente o crescimento e a sobrevivência de outra espécie. No caso do gênero Trichoderma, a competição está relacionada à capacidade de obter nutrientes com maior eficiência do que os patógenos, o que se reflete na sua alta taxa de reprodução e crescimento (BENITEZ et al, 2004). A antibiose é definida como o conjunto das interações que envolvem compostos de baixo peso molecular ou antibióticos produzidos por um microrganismo que têm um efeito direto sobre outro. Durante a antibiose ocorre a produção de metabólitos secundários que interferem no crescimento de outros fungos ou através da acidificação do solo, como compostos fungistáticos ou mesmo degradando as células dos patógenos (LORITO et al., 2010). O micoparasitismo é o mecanismo mais típico de controle de patógenos realizado por Trichoderma; no qual estão envolvidos o reconhecimento e o crescimento em direção à hifa hospedeira, com posterior secreção de enzimas que degradam a parede celular do fungo alvo, podendo haver a introdução de hifas no parasita (DRUZHININA, 2011).

Ao colonizarem as raízes das plantas, espécies de Trichoderma provocam indução de mecanismos de defesa das plantas, MAMPs (Padrões moleculares associados a microrganismos) são capazes de ativar a resposta imune inata e desencadear de forma rápida e transitória respostas de defesa como aumento do fluxo de íons através da membrana do plasmática, produção de espécies reativas de oxigênio (ROS), produção de óxido nítrico, síntese de compostos antimicrobianos e ativação das vias de sinalização do ácido jasmônico e etileno (DRUZHININA et al., 2011).

Outro mecanismo proposto para explicar o controle de fitopatógenos pelo Trichoderma ocorre de forma indireta onde compostos produzidos pelas plantas colonizadas promovem proteção contra doenças, estimulam o crescimento e tolerância a estresses bióticos e abióticos (HERMOSA et al., 2012) O mecanismo de promoção do crescimento ocorre devido à ação de vários fatores, envolvendo a produção de hormônios vegetais ou conversão de materiais de forma útil para a planta, absorção e 
translocação de minerais. Na colonização da raiz, além do reconhecimento e adesão, as estirpes de Trichoderma têm que ser capazes de penetrar nos tecidos da planta, e suportar metabólitos tóxicos produzidos em resposta ao patógeno, hidrofobinas estão relacionadas com a aderência, proteínas tipo expansinas e endopoligalacturonase estão envolvidas na modificação da arquitetura e degradação da parede celular da planta, facilitando a colonização da raiz.

\subsection{O estudo do biocontrole de Trichoderma}

A necessidade de aumentar a produtividade agrícola levou a um uso intensivo de agrotóxicos para o controle de pragas e doenças de plantas, criando problemas de ordem ambiental. $\mathrm{O}$ controle biológico tem sido apontado como um método alternativo para o manejo das doenças de plantas e a manutenção da alta produtividade com baixo impacto ecológico (HIROOKA \& ISHII, 2013; HYAKUMACHI, 2013).

O uso de Trichoderma na agricultura aparece como um método promissor para reduzir ou eliminar o uso de fungicidas e pesticidas. Entretanto, sua eficácia varia com o agente de biocontrole utilizado, o patógeno a ser combatido, o genótipo a ser protegido, além de sofrer interferência de fatores como o tipo de solo, temperatura, $\mathrm{pH}$ e outros componentes da microbiota local (HOWELL, 2003). Diversas moléculas estão envolvidas durante o processo de biocontrole realizado por Trichoderma: enzimas hidrolíticas, antibióticos, metabólitos voláteis, moléculas de resistência ao estresse e de indução de resistência em plantas. Essa variedade de moléculas ilustra a complexidade da base genética do biocontrole (MASSART \& JIJAKLI, 2007). Assim, é preciso uma melhor compreensão dos aspectos moleculares do processo de biocontrole para a utilização desse organismo, suas proteínas ou seus genes (KUBICEK et al., 2011, LORITO et al., 2010, VINALE et al., 2008).

Nos últimos anos, as interações que ocorrem entre Trichoderma e fungos fitopatogênicos de plantas estão sendo intensamente investigadas. Técnicas de genômica e transcriptômica estão sendo utilizadas para analisar os mecanismos moleculares envolvidos no controle biológico (SAMOLSKI, 2009). As ESTs (expressed sequence tags) são oriundas de mRNA que são convertidos em cDNA. Esses segmentos de cDNA tecido-específicos são sequenciados e identificados através da bioinformática por comparação em bancos de dados de ESTs de várias espécies (ADAMS et al., 1991). A 
utilização das bibliotecas ESTs é uma maneira eficaz de identificar novos genes, para explorar os padrões de expressão e regulação da expressão gênica (BAILEY et al., 2006). Assim, as análises de ESTs se tornaram uma poderosa ferramenta que tem sido utilizada em diversos trabalhos para explorar genes de Trichoderma expressos em diferentes condições de cultivo, durante a interação com fitopatógenos e plantas (LIU \& YANG, 2005; STEINDORFF et al., 2012).

O primeiro estudo de ESTs de Trichoderma foi realizado por LIU e YANG (2005), no qual foram sequenciados 3298 cDNAs, sendo que 55 apresentaram similaridade com proteínas envolvidas no controle biológico. Estes foram então classificados de acordo com seus possíveis mecanismos de ação: ação antifúngica (23 cDNAs), micoparasitismo (22 cDNAs), competição por espaço e nutrientes (5 cDNAs) e inativação do patógeno (5 cDNA).

Iniciado em 2002, um consorcio internacional chamado TrichoEST "Functional genomics and proteomics of Trichoderma antagonist strains for industry and agriculture”, visou entender os mecanismos utilizados pelo fungo Trichoderma e identificar genes com valor biotecnológico utilizando técnicas de genômica e proteômica. Deste projeto foram sequenciados 25.000 ESTs e 13.814 transcritos, para oito espécies diferentes de fungos: T. harzianum, T. virens, T. atroviride, T. viride, $T$. longibrachiatum, T. stromaticum, T. aggressivum, e T. asperellum (LORITO et al., 2010), e foram publicados dois artigos. No primeiro trabalho, VIZCAÍNO et al., (2006) construíram oito diferentes bibliotecas de $T$. harzianum crescido em diferentes condições de crescimento, nutrientes e estresse, e foram gerados 8.710 ESTs. Destes, foi identificado um total de 3.478 sequências únicas incluindo 6 quitinases, 30 glucanases e 54 proteases. Dentre os genes mais expressos durante o estresse do micoparasitismo estava uma hidrofobina. No segundo artigo, VIZCAÍNO et al (2007) mostraram a construção de quatro bibliotecas com quatro espécies diferentes, onde os genes mais expressos foram sequências similares a hidrofobina. STEINDORF et al (2012) pretendendo entender melhor as vias do mecanismo de biocontrole, construíram uma biblioteca de cDNA a partir do micélio de Trichoderma harzianum crescido em parede celular isolada de Fusarium solani. Foram obtidos 3984 clones que mostraram 
similaridade com diferentes genes que codificam para enzimas, proteínas estruturais, fatores de regulação e ainda genes envolvidos no processo de micoparasitismo.

Diversas metodologias para a análise da expressão diferencial vêm sendo empregadas para identificar genes envolvidos no processo do micoparasitismo de Trichoderma. A técnica de subtração por hibridização subtrativa ou SSH (Suppression Subtractive Hybridization) é utilizada para isolar e clonar genes diferencialmente expressos entre duas populações de cDNA, sintetizados a partir de mRNAs obtidos de condições distintas. Essa técnica permite o enriquecimento dos transcritos diferencialmente expressos, facilita a clonagem de genes que estão relacionados a um processo específico, e apresenta a vantagem de ser bastante eficiente para a obtenção de genes pouco abundantes (REBRIKOV et. al. 2008).

A hibridização subtrativa por supressão é um método que utiliza o principio da hibridização de ácidos nucleicos para o refinamento de duas populações de cDNA O primeiro passo da técnica é sintetizar moléculas de cDNA utilizando mRNA da condição de interesse. Estes cDNA são então hibridizados com um grande excesso de moléculas de mRNA da condição controle. O cDNA da condição teste é digerido e separado em dois grupos para serem ligados, cada um, a adaptadores distintos, estes possuem regiões de anelamento para uma futura reação de PCR. Na primeira etapa de hibridização, os dois conjuntos do cDNA teste são misturados ao controle separadamente enquanto na segunda etapa, as duas hibridizações são misturadas e novamente hibridizadas. Isso permite aos genes diferencialmente expressos formar híbridos contendo, em cada fita um dos dois adaptadores. Em seguida, por PCR, fragmentos de genes diferencialmente expressos são amplificados e podem ser clonados (LUKYANOV et al., 2007)

Diversos trabalhos fizeram o uso da técnica de SSH para identificar genes diferencialmente expressos de Trichoderma. CARPENTER et al. (2005) investigaram os genes envolvidos na interação entre T. hamatum e Sclerotinia sclerotiorum. Utilizando confronto in vivo em placas de Petri, foram encontrados 25 genes, destes, 19 apresentaram expressão durante a interação com S. sclerotiorum. (SCHERM et al., 2008) utilizaram biblioteca subtrativas RaSH (rapid subctrative hybridization) clonaram 
genes que são expressos especificamente durante a interação com o fitopatógeno Rhizoctonia solani,

Genes de Trichoderma com potencial uso biotecnológico para transformação de plantas foram recentemente identificados por VIEIRA et al. (2013) através da análise de bibliotecas subtrativas. Vários genes diferencialmente expressos em Trichoderma harzianum durante contato com Fusarium solani foram identificados, e pela análise de suas sequências foi possível inferir suas funções durante o desenvolvimento, metabolismo e controle biológico realizado por T. harzianum. A quantificação da expressão de alguns desses genes foi analisada por PCR em tempo real (RT-qPCR) e dentre os genes candidatos que tiveram a expressão aumentada, o gene da esfingomielinase destacou-se no primeiro contato entre os fungos; e provavelmente devido à sua atividade de hidrolase, que cliva esfingolípidos presentes na membrana plasmática, sua função durante o contato pode estar associada à resposta ao fitopatógeno para degradação da membrana. Por esta razão, o gene da esfingomielinase foi selecionado como gene candidato para transformação de plantas de tabaco.

\subsection{Desestabilizando a membrana, uma forma de desenvolvimento de terapias antimicrobiana e antifúngica.}

A principal característica das membranas biológicas é a dupla camada de lipídeos, restringindo a passagem de moléculas polares e íons. Os esfingolipídeos são componentes estruturais de membranas celulares envolvidos no crescimento e proliferação celular (OBEID et al. 2002; SIMS et al., 2004). Além disso, essas moléculas são importantes na regulação e diferenciação celular, apoptose e senescência (BIEBERICH, 2004; MACEYKA et al, 2002).

Os esfingolipídeos compõe uma classe de lipídeos de membrana que têm um grupo-cabeça polar e duas caudas não polares, formados por três estruturas básicas: uma molécula de amino-álcool de cadeia longa (esfingosina), uma molécula de ácido graxo de cadeia longa, e um grupo polar unido ou por uma ligação glicosídica ou por uma ligação fosfodiéster (Figura 1). 


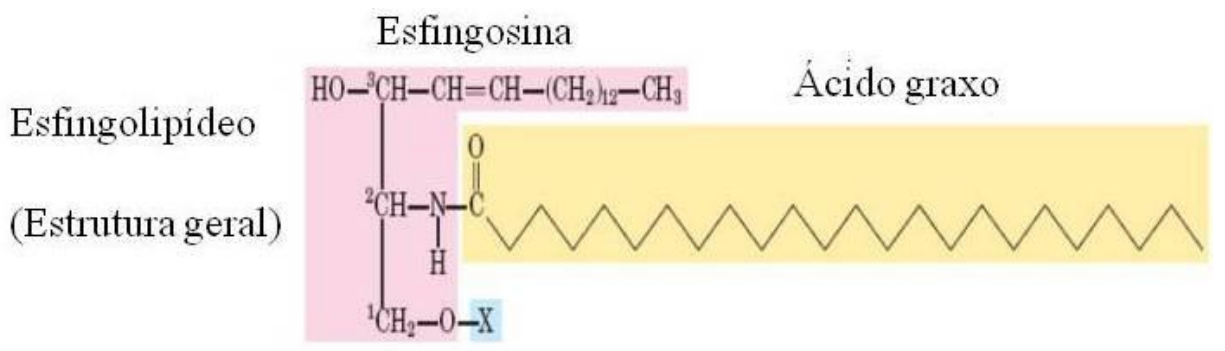

Figura 1: Estrutura geral dos esfingolipídeos de membrana (NELSON \& COX, 2011)

Existem três subclasses de esfingolipídeos que são derivados das ceramidas, mas contendo grupos cabeça diferentes: esfingomielina, glicolipídeos neutros e gangliosídios. Na literatura seu papel está ligado a regulação das vias de sinalização, controlando processos celulares essenciais incluindo diferenciação, migração celular, apoptose e resposta a inflamação (DICKSON, 2008)

Os esfingolípidos são componentes essenciais da membrana plasmática de células de mamífero, mas também são componentes de membrana de alguns grupos de bactérias, em particular as anaeróbias e Gram negativas (OSLEN, 2001).

Esfingomielinases (SMase) são um grupo de enzimas que catalisam a hidrólise de esfingomielina (Figura 2), liberando ceramida e fosforil colina (MILHAS, 2010). Existem seis tipos de SMases: SMase ácida, SMase secretora, SMase neutra dependente de magnésio, SMase neutra independente de magnésio, SMase alcalina e SMase bacteriana (GONI \& ALONSO, 2002). Uma função importante das esfingomielinases está relacionada a propriedade de alterarar a carga da membrana, sua fluidez e permeabilidade.

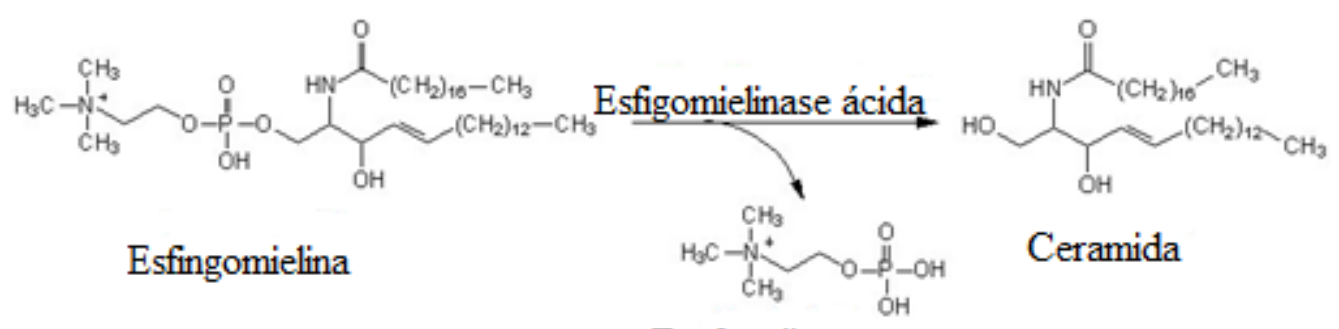

\section{Fosfocolina}

Figura 2: Representação gráfica da atividade da esfingomielinase ácida liberando fosforil colina e ceramida (KING, 2014) 
A esfingomielinase ácida foi a primeira enzima da classe de esfingolipídios descrita e foi demonstrado que ela está envolvida na regulação celular através da hidrólise de esfingomielina para formar ceramida. O sistema esfingomielinase-ceramida está associado à resposta do hospedeiro para internalização de agentes patogênicos, na indução de apoptose em células infectadas, na ativação de vias de sinalização intracelular, na proliferação celular, no crescimento, diferenciação e autofagia (GRASSMÉ \& BECKER, 2013, PERROTA et al. 2015).

A esfingomielinase ácida é uma importante enzima no metabolismo dos esfingolipídios que pode ser ativada por estresses causados por infecções bacterianas, a ativação de esfingomilinase gerando ceramida atua como um mensageiro secundário na indução de a resposta imune para eliminar agentes patogénicos infectados ( $\mathrm{Yu}$ et al. 2009).

Esfingomielinases D (SMases D), também conhecidas como esfingomielina fosfodieasterases D, estão bem caracterizadas em venenos de aranha Loxosceles e têm sido descritas em novos organismos tais como bactérias, carrapatos, ácaros e fungos (DIAS-LOPES, 2013). Os autores sugerem que esta sequencia conservada de aminoácidos pode estar atuando como um efetor patogênico comum nestes diferentes agentes.

Segundo Binford et al. (2005) existem três cenários evolutivos para explicar as semelhanças entre esfingomielinases de aranhas e bactérias: 1) Esfingomielinases de bactérias e aranhas podem ter evoluído independente da mesma família geral de proteínas; 2) Esfingomielinases-D podem ser originadas de uma única linhagem e se movido via transferência horizontal; 3) As similaridades não resultam de um ancestral comum, mas refletem uma convergência para desempenhar uma função comum. A Esfingomielinase-D presente nesses organismos filogeneticamente distantes são similares em massa molecular (30-35 kDa), carga, substrato específico, resíduos de aminoácidos conservados no domínio N-terminal e outras características físico químicas, estruturais e biológicas. A análise filogenética proposta por Dias-Lopes (2013) diverge do proposto e ressalta a necessidade de se explorar a origem evolutiva e função em cada organismo. 


\subsection{Transformação genética de plantas utilizando genes de Trichoderma.}

A obtenção de organismos geneticamente modificados através da técnica do DNA recombinante ampliou as possibilidades de melhoramento genético. O processo pode ser feito de forma direta, através de métodos físicos como a eletroporação de protoplastos e bombardeamento de micropartículas; ou de forma indireta através de um vetor biológico, como Agrobacterium tumefaciens e A. rhizogenes (BRASILEIRO \& DUSI, 2002; RECH \& ARAGÃO, 1999). Plantas transgênicas são importantes ferramentas para estudos moleculares de expressão e função gênica, de processos fisiológicos e desenvolvimento vegetal.

A técnica de transformação de plantas com genes de Trichoderma é utilizada para entender o papel dos genes envolvidos no processo de controle biológico, na busca por plantas resistentes a fitopatógenos e tolerantes a stress abióticos (NICOLÁS et al. 2014) Entre os genes mais expressos de Trichoderma estão quitinases e glucanases, no trabalho pioneiro de LORITO et al. (1998) foi demonstrado que a expressão do gene de uma quitinase (chit42) de Trichoderma harzianum conferiu resistência em plantas de tabaco e batata aos fitopatógenos foliares Alternaria alternata, A. solani, Botrytis cinerea e o patógeno de solo Rhizoctonia solani. Outros estudos com plantas transgênicas expressando genes de Trichoderma corroboraram esta afirmação (BOLAR, 2000) expressando a endoquitinase (chit42) em plantas de maça verificaram a resistência a Venturia inaequalis, mas uma redução no crescimento. Outro gene homologo (chit42) de T. virens mostrou resistência contra Rhizoctonia solani quando expressa em arroz (SHAH et al., 2009), a endoquitinase (chit40) de T. harzianum obtida da cultura de células de tabaco inibiu a germinação conidial do patógeno Penicillium digitatum (BRANTS \& EARLE, 2001). No mesmo caminho (LIU et al., 2004) utilizaram a expressão de duas quitinases (ech42 e nag70) e uma glucanase (gluc78) resultando na resistência a $R$. solani e Magnaporthe grisea em arroz.

Assim a geração de plantas com genes de Trichoderma tem demonstrando resultados positivos no controle de doenças de plantas, onde essas plantas eram tolerantes ou completamente resistentes a patógenos (BOLAR 2000; HERMOSA et al., 2012, KUMAR et al., 2009, MONTERO-BARRIENTOS et al., 2010, SUAREZ et al., 2004). 
Nesse trabalho o tabaco ( Nicotiana tabacum L.) foi escolhido como modelo para testar nossas premissas. O tabaco é uma planta uma planta herbácea anual, pertencente ao gênero Nicotiana, família Solanaceae de acordo com a classificação APG III (2009). É de fácil cultivo, com crescimento rápido e ciclo reprodutivo curto. Além da importância econômica, o tabaco é utilizado como organismo modelo nas pesquisas de transformação genética, pois existe um protocolo estabelecido para transformação usando Agrobacterium tumenfaciens e de regeneração de explantes foliares. É uma planta de ciclo curto e suscetível tanto a Sclerotinia quanto a Pseudomonas. As doenças que mais afetam a cultura do tabaco são o fogo selvagem e a mancha angular ambas causadas pela bactéria Pseudomonas syringae pv. tabaci. Entre os muitos genes expressos em plantas de tabaco destacam-se os genes focados na resistência a patógenos e a ativação de diferentes mecanismos de defesa. Para verificar a eficiência da estratégia o sistema experimental utilizando estirpes de Pseudomonas syringae é um modelo para validar a atuação dos genes na interação planta-patógeno antes de inserir o gene em uma cultura de interesse econômico. 


\section{JUSTIFICATVA}

Os fungos da classe Trichoderma sp. são mundialmente conhecidos pela sua atuação como agente do controle biológico de fitopatógenos de plantas. A engenharia genética trouxe avanços significativos sobre as enzimas secretadas pelas estirpes de Trichoderma durante o processo de biocontrole. Dentro deste arsenal enzimático, a esfingomielinase se destacou por apresentar altos valores de expressão durante o início do antagonismo ao fitopatógeno Fusarium. Esfingolipideos, que são substratos dessa enzima, são alvos de terapias antimicrobianas e antifúngicas. Com base nesta premissa acreditamos em uma função de defesa para a enzima esfingomielinase. Pesquisas da expressão de genes de Trichoderma $s p$ podem revelar aplicações agrícolas do seu arsenal enzimático. Nesse estudo optou-se por testar as premissas levantadas em plantas de tabaco que é um organismo modelo, com o protocolo de transformação já bem estabelecido, ciclo de vida curto e genoma sequenciado. 


\section{HIPÓTESE}

A expressão do gene que codifica uma esfingomielinase de Trichoderma em $N$. tabacum poderá gerar plantas mostrando tolerância a patógenos. 


\section{OBJETIVO}

O objetivo geral deste trabalho é expressar o gene de uma esfingomielinase de Trichoderma virens em $N$. tabacum e avaliar a sua capacidade de induzir resistência a fitopatógenos (fungos e bactérias).

\subsection{Objetivos específicos}

- Construir um vetor de expressão contendo um gene da esfingomielinase sob o controle do promotor constitutivo do RNA 35S do Cauliflower mosaic virus (CaMV) duplicado, e de uma sequência enhancer não traduzida do Alfalfa mosaic virus (AMV).

- Transformar geneticamente plantas de tabaco via Agrobacterium tumefaciens.

- Analisar as linhagens geneticamente modificadas para a expressão dos transgenes.

- Realizar bioensaios para avaliação de resistência das plantas ao fungo fitopatogênico Sclerotinia sclerotiorum.

- Realizar bioensaios para avaliação de resistência das plantas a bactéria Pseudomonas syringae pv. tabaci 


\section{MATERIAL E MÉTODOS}

\subsection{Material vegetal}

Plantas cultivadas in vitro de Nicotiana tabacum cv. Xanthi mantidas com repicagens periódicas em meio de cultura MS (MURASHIGE \& SKOOG, 1962), fotoperíodo de $16 \mathrm{~h}$ à temperatura de $25 \pm 2^{\circ} \mathrm{C}$.

\subsection{Construção do vetor de expressão contendo o gene de esfingomielinase}

A sequência da proteína de uma esfingomielinase ácida de Trichoderma virens Gv29-8 depositada no GenBank (http://www.ncbi.nlm.nih.gov/) acesso (EHK26001.1) foi utilizada para que esta fosse quimicamente sintetizada pela empresa Epoch Inc., USA.. O gene foi sintetizado utilizando-se os códons preferenciais de Arabidopsis thaliana. O fragmento dessa sequência foi clonado no vetor pC3300GCHI entre os sítios de NcoI e SacI, sob o controle do promotor RNA35SCaMV. O vetor possui ainda o gene bar que codifica para a enzima fosfinotricina acetil transferase (PAT) que confere tolerância ao herbicida glifosinato de amônio (GA), utilizado para selecionar as plantas geneticamente modificadas.

\subsection{Transformação de $E$. coli por eletroporação e extração de DNA plasmidial (Miniprep)}

Um tubo eppendorf contendo células competentes foi descongelado em banho de gelo e uma alíquota de $2 \mu \mathrm{L}$ de DNA foi adicionada às bactérias E. coli DH5 $\alpha$, e o tubo incubado no gelo por 2 minutos. Após este período, a mistura de células e DNA foi colocada numa cubeta de eletroporação previamente resfriada. A eletroporação foi realizada em aparelho "BioRad". Imediatamente após a eletroporação foram adicionados $600 \mu \mathrm{L}$ de meio LB, e as células foram suspensas e transferidas para um tubo eppendorf. A mistura foi, então incubada à $37^{\circ} \mathrm{C}$ durante 40 minutos. Após esta etapa, foram plaqueados diferentes volumes da cultura bacteriana em uma placa de Petri contendo $25 \mathrm{ml}$ de meio LB sólido acrescido de canamicina $100 \mathrm{mg} / \mathrm{L}$, após este procedimento as placas foram incubadas a $37^{\circ}$ durante a noite.

Para a execução da miniprep foram coletados $3 \mu \mathrm{L}$ da cultura bacteriana liquida gerada a partir de uma colônia transformada e incubada em $3 \mathrm{~mL}$ de LB liquido contendo $100 \mathrm{mg} / \mathrm{L}$ de canamicina à $37^{\circ} \mathrm{C}$ e $180 \mathrm{rpm}$. Para a extração do DNA 
plasmidial foi utilizado o kit Wizard $^{\circledR}$ Plus SV Miniprep (PROMEGA) segundo as recomendações do fabricante.

A clonagem foi confirmada através da clivagem com a enzima de restrição Eco RI, à $37^{\circ}$ por 2 horas, gerando dois fragmentos de 2020 e 9235 bp.

\subsection{Transformação de Agrobacterium tumefaciens por eletroporação}

O vetor pC3300GCHI.Sphingo foi transferido para a linhagem de Agrobacterium tumefaciens EHA 105 por eletroporação como descrito por (LACORTE \& ROMANO, 1998). Após a eletroporação foram adicionados $1 \mathrm{~mL}$ de meio $\mathrm{LB}$, e as células foram suspensas e transferidas para um tubo eppendorf. A mistura foi, incubadas à $28{ }^{\circ} \mathrm{C}$ durante 4 horas. Após esta etapa, foram plaqueados diferentes volumes da cultura bacteriana em placa de Petri contendo $25 \mathrm{ml}$ de meio LB sólido acrescido de rifampicina $100 \mathrm{mg} / \mathrm{L}$ e canamicina $100 \mathrm{mg} / \mathrm{L}$, após este procedimento as placas foram incubadas a $28^{\circ}$ durante a $48 \mathrm{~h}$.

Colônias isoladas foram coletadas individualmente com auxilio de uma ponteira estéril, inseridas em $20 \mu \mathrm{L}$ de água e posteriormente fervidas por 5 minutos. Para a reação de PCR foi utilizado $2 \mu \mathrm{L}$ da solução bacteriana como DNA molde e os primers 35SCamvF: CCACTATCCTTCGCAAGAC $e$ TnosR: ATCATCGCAAGACCGGCA que na reação amplificam uma sequência de $2220 \mathrm{pb}$, da região promotora ao terminador contendo entre eles a região codificante da esfingomielinase.

\subsection{Transformação genética de plantas de tabaco}

A linhagem de Agrobacterium tumefaciens EHA 105 contendo o vetor pC3300GCHI.Sphingo foi inoculada em $10 \mathrm{~mL}$ de meio LB (MILLER, 1972) contendo os antibióticos $100 \mathrm{mg} / \mathrm{L}$ rifampicina, $100 \mathrm{mg} / \mathrm{L}$ canamicina. A cultura cresceu por $16 \mathrm{~h}$ a $28^{\circ} \mathrm{C}$ sob agitação de $100 \mathrm{rpm}$ até a fase exponencial de crescimento até uma densidade ótica (D.O.) de 0,7 ( $\left.\mathrm{A}_{600 \mathrm{~nm}}\right)$. Após o crescimento da cultura bacteriana foi realizado o corte das folhas jovens de plantas de Nicotiana tabacum cv. Xanthi mantidas in vitro. As folhas foram cortadas em quadrados de $1 \mathrm{~cm}^{2}$ com auxílio de uma lâmina de bisturi estéril, numa placa de Petri umedecida com água deionizada estéril para mantê-los hidratados. Os explantes foliares foram transferidos para placa de Petri contendo a suspensão bacteriana (cocultura líquida) onde permaneceram a temperatura 
ambiente por 10 min e com leve agitação. Tendo sido transferidos para uma placa de Petri com papel de filtro autoclavado com a finalidade de retirar o excesso de suspensão bacteriana. Em seguida, foram inoculados em meio MS sólido contendo BAP (6benzilaminopurina) $1 \mathrm{mg} / \mathrm{L}$ com a face adaxial em contato com o meio por $48 \mathrm{~h}$ a $25 \pm$ $2^{\circ} \mathrm{C}$ no escuro. Após dois dias de cocultura sólida, os explantes foram transferidos para meio de regeneração MS contendo BAP $2 \mathrm{mg} / \mathrm{L}$, cefotaxima $200 \mathrm{mg} / \mathrm{L}$, timentin 100 $\mathrm{mg} / \mathrm{L}$ e glifosinato de amônio (GA) $5 \mathrm{mg} / \mathrm{L}$. As placas foram mantidas em câmara de crescimento sob fotoperíodo de $16 \mathrm{~h}$ a $25 \pm 2^{\circ} \mathrm{C}$. Os explantes foram cultivados por duas semanas e os calos obtidos foram separados e transferidos para novo meio de regeneração contendo GA. Os brotos tolerantes ao herbicida foram transferidos para o meio de enraizamento que consistiu de meio MS contendo ANA com 5 mg/L de GA. As plântulas transgênicas regeneradas foram aclimatadas em casa de vegetação até a produção e colheita das sementes.

\subsection{Análise das plantas regeneradas}

As plantas tolerantes ao glifosinato foram submetidas a testes para analisar a presença do transgene por PCR, a expressão do gene de seleção introduzido pela detecção da presença de fosfinotricina acetil transferase com o Teste Kit GMO Trait chek LL (Strategic Diagnostic Inc.)

\subsubsection{PCR para detecção do gene esfingomielinase}

A análise molecular visando a detecção do gene da Esfingomielinase foi realizada utilizando o DNA extraído de discos foliares, segundo protocolo de extração com CTAB (BRASILEIRO, 1998b). Para cada amostra analisada o DNA foi adicionado à solução contendo água destilada, $\mathrm{dNTP}, \mathrm{MgCl}_{2}$, Taq polimerase e os primers Sphingo F: TGGACAAGATGGGTTGGAGC e Sphingo R: GCCATAACAGCATGAGAAGCA utilizados irão amplificar uma sequência de 412 pb contida na região codificante do gene da esfingomielinase.

Os produtos da PCR foram submetidos à eletroforese em gel de agarose $2 \%$ usando tampão TBE $0,5 \mathrm{X}$. 


\subsubsection{Teste para detecção da proteína PAT}

Um disco foliar de cada planta de tabaco foi macerado com bastão de vidro em tubo de microcentrífuga tipo Eppendorf, onde foi adicionado ao extrato vegetal $200 \mu \mathrm{I}$ de tampão PBS 1X. Em seguida uma tira do Teste GMO TraitCheck (gene bar - PAT) foi inserida no tubo de microcentrífuga, com a seta indicativa voltada para baixo.

\subsubsection{Análise da segregação das $\mathbf{T}_{1}$}

Para selecionar as plantas positivas para os bioensaios foram utilizadas 15 plantas de 10 eventos $T_{1}$, foi aplicada sobre a face adaxial das plântulas uma solução com o herbicida glifosinato de amônio $200 \mathrm{mg} / \mathrm{mL}$.

\subsection{Bioensaios}

Plantas transgênicas de tabaco expressando o gene de Esfingomielinase foram testadas para resistência ao fungo fitopatogênico Sclerotinia sclerotiorum. como descrito por Dias et al. (2006).

\subsection{Produção do inoculo de fungo}

Estirpes de Sclerotinia foram cultivados em placa de Petri com meio BDA (Batata Dextrose Agar), visando o desenvolvimento de micélios. Para a produção do inóculo utilizado no bioensaio com folhas, um disco de micélio de $5 \mathrm{~mm}$ de diâmetro foi retirado do halo formado e colocado no centro de uma nova placa contendo meio BDA. As placas foram mantidas na sala de cultivo com temperatura ambiente de $20^{\circ} \mathrm{C}$ e retiradas após 96 h para realização dos testes.

\subsection{Teste das folhas destacadas}

Os experimentos foram realizados utilizando folhas de plantas transgênicas cultivadas em casa de vegetação apresentando o mesmo estágio de desenvolvimento. Uma folha de cada planta $T_{1}$ foi retirada e imediatamente depositada em uma vasilha com água para o transporte. As amostras foliares foram posicionadas em caixas Gerbox contendo 3 folhas de papel de filtro umedecidas. Discos de micélio de $5 \mathrm{~mm}$ de diâmetro retirados das margens do halo formado pelo fungo em crescimento foram posicionados na superfície adaxial da folha. As caixas contendo os trifólios inoculados foram transferidas para sala de cultivo e mantidas em temperatura ambiente $20^{\circ} \mathrm{C}$ no escuro. 
As folhas inoculadas foram fotografadas após 48, 72 horas de cultivo. As imagens foram usadas para medição da área afetada em cada estágio com o auxilio do programa IMAGE J (imagej.nih.gov/ij/)

\subsection{Infiltração com Pseudomonas syringae pv. tabaci}

A cepa bacteriana de Pseudomonas syringae pv. tabaci Emb 135 gentilmente cedida pela Dra. Abi Marques em nome do Instituto Biológico de São Paulo IBSBF, foi utilizada para os ensaios de infiltração conforme descrito por Li e colaboradores 2000

A cepa bacteriana Emb 135 (IBSBF 766) foi estriada na placa de Petri contendo o meio sólido 523, desenvolvido por Kado \& Heskett (1970), e incubada a $28^{\circ} \mathrm{C}$. Após 24 horas, o material de uma colônia foi recuperado e cresceu em meio 523 liquido por 48 horas sob agitação $150 \mathrm{rpm}$. Depois deste período de incubação, a cultura foi centrifugada e ressuspendida em água destilada utilizando a escala de Mc Farland na diluição de $10^{-7}$.

A infiltração nas folhas destacadas foi realizada com uma seringa sem agulha na sua parte abaxial, após a infiltração as folhas foram mantidas em bandejas contendo papel umedecido e envolvidas com sacos plásticos para simular uma câmara úmida, As bandejas foram mantidas em câmara de crescimento sob fotoperíodo de $16 \mathrm{~h}$ a $25 \pm 2^{\circ} \mathrm{C}$.

Cinco plantas de cada linhagem foram utilizadas em duas repetições com a bactéria $P$. syringae. Em cada folha destacada foram infiltrados 6 pontos com a suspensão bacteriana e um ponto com água. As folhas destacadas foram fotografadas para o cálculo das áreas lesionadas e a leitura com o clorofilômetro foi realizada em três pontos ao redor dos locais de infiltração da bactéria. As duas repetições foram avaliadas com 7 e 14 dias após a infiltração para avaliar o progresso do crescimento bacteriano.

Para avaliarmos o experimento utilizamos leitor de clorofila Opti-science CCM200 e o programa Image $J$ para medida da área ao redor da infiltração. A avaliação foi realizada com 7,10 e 14 dias.

\subsection{Recuperação de $P$. syringae pv tabaci das regiões infiltradas.}

Discos de $5 \mathrm{~mm}^{2}$ com sintomas de amarelecimento ao redor do halo de infecção foram desinfestados através da imersão em álcool $70 \%$ por 1 minuto, hipoclorito de 
sódio $1 \%$ por 1 minuto, e depois de lavados em água destilada esterilizada os discos foram inseridos em tubos de microcentrifuga $(1,5 \mathrm{ml})$ contendo água destilada. Foram centrifugados 5 segundos à $13.400 \mathrm{rpm}$, e $50 \mu \mathrm{L}$ da suspensão bacteriana foram transferidos para os meios semi seletivos SPA com Sacarose, $20 \mathrm{~g} / \mathrm{L}$ Peptona 10g/L e Agar 12 g/L e 0,05\% de Cloreto trifenil tetrazólio (Silveira, 2002); e para o meio MSP (Mohan \& Schaad, 1987) composto por Sacarose 20g/L, peptona 5g/L, K $\mathrm{HPO}_{4}$, $\mathrm{MgSO}_{4} .7 \mathrm{H}_{2} \mathrm{O} 25 \mathrm{mg} / \mathrm{L}$, Agar $20 \mathrm{~g} / \mathrm{L}$ e bromotimol azul (15 mg/L).

\subsection{Análises estatísticas}

Foi utilizado o programa Microsoft Excel para a organização dos dados, a análise dos foram desenvolvidas no programa de linguagem estatística R. Primeiramente checou-se a normalidade dos dados através do teste de Shapiro-Wilk. Se os dados apresentassem normalidade foi utilizada a ANOVA paramétrica seguida do teste de comparação múltipla Scott Knott. Caso os dados não apresentassem normalidade aplicava-se a transformação matemática logarítmica. Para todas as análises, considerou-se $\mathrm{p}<0,05$ de significância estatística. 


\section{RESULTADOS}

\subsubsection{Construção do vetor contendo o gene da esfingomielinase}

Após o desenho in silico do cassete de expressão do gene da esfingomielinase foi sintetizado o vetor pC3300GCHI-Sphingo (Figura 3). Depois de inserido em células de E. coli estirpe XL1 Blue sua presença foi confirmada através da liberação de um fragmento de 2020 pb correspondente à região codificante do gene da esfingomielinase dos clones 3 e 4 que possuem o inserto, através da digestão com Nco I e Sac I e dos 9 e 10 digeridos com Eco RI (Figura 4).

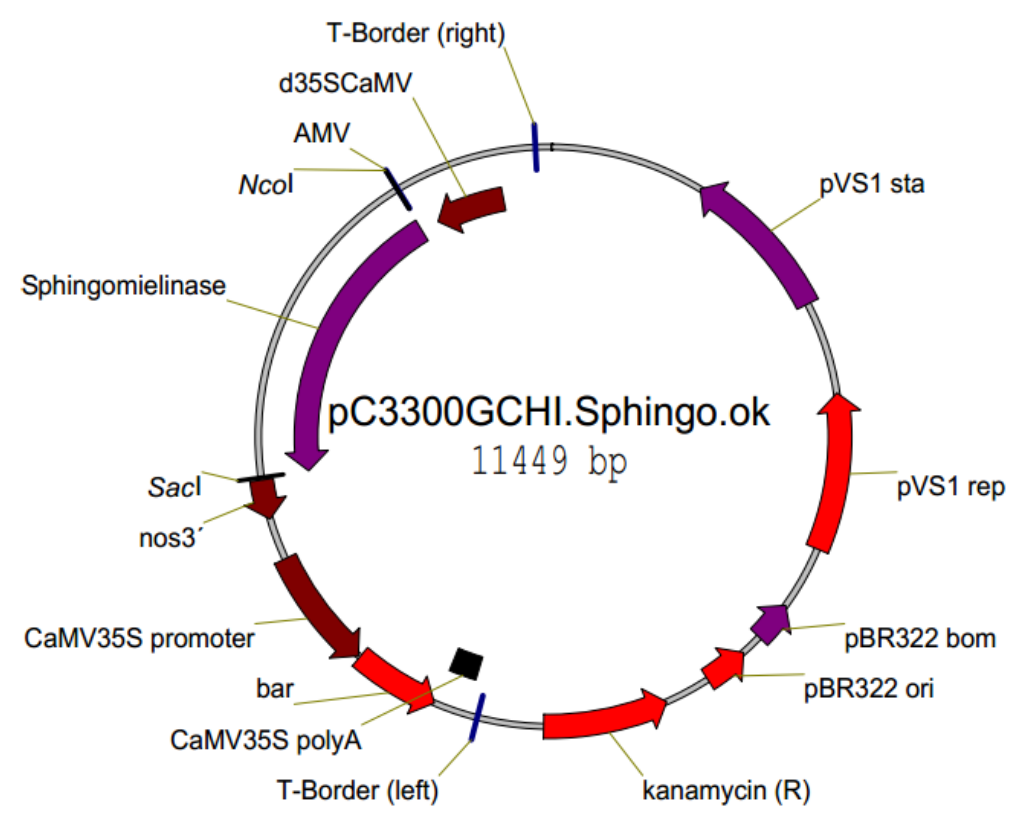

Figura 3: Representação esquemática do vetor pC3300GCHI.Sphingo contendo o promotor CaMV35S (do Cauliflower mosaic virus) dirigindo a expressão do gene da esfingomielinase com o terminador nos3' (do gene nopalina sintase de A. tumefaciens), o gene de resistência para planta bar, e o gene nptI que confere resistência a canamicina. 


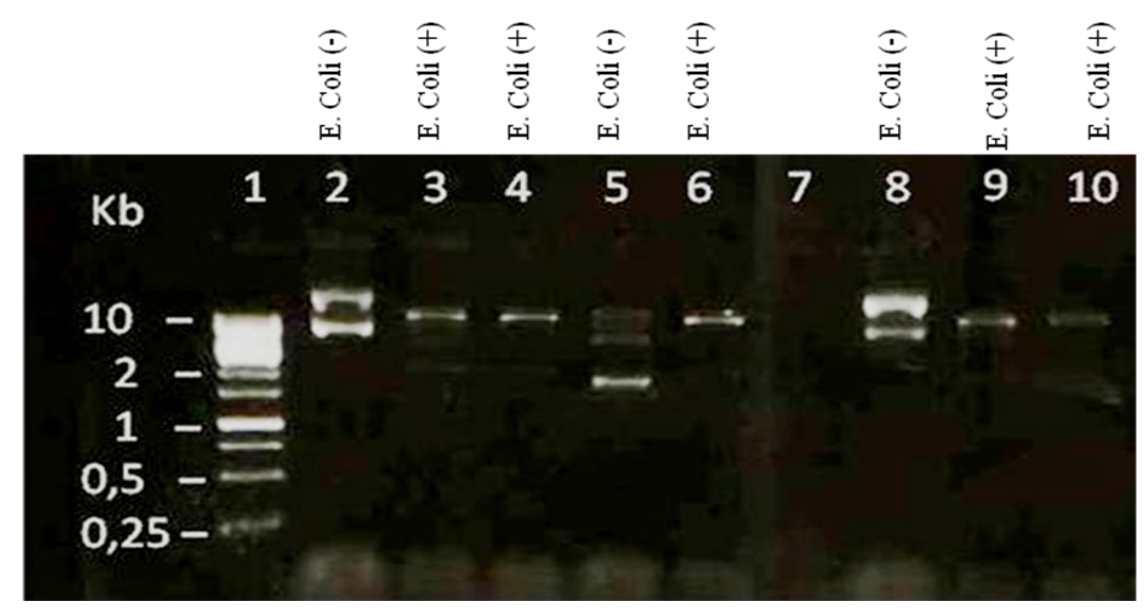

Figura 4: Gel de agarose (1\%) mostrando a digestão do vetor pC3300GCHI-Sphingo com as enzimas Nco I/Sac I e Eco RI. Poço1: marcador de massa molecular $1 \mathrm{~kb}$ Ladder (Invitrogen), Poço 2: clone 1 negativo de E. coli digerido com enzimas Nco I/Sac I, Poço 3: clone 2 positivo de E. coli digerido com enzimas Nco I/Sac I, Poço 4: clone 3 positivo de E. coli digerido com enzimas Nco I/Sac I, Poço 5: clone 4 de E. coli digerido com enzimas Nco I/Sac I, Poço 6: clone de E. coli digerido com enzimas Nco I/Sac I. Poço 8: clone 1 negativo de E. coli digerido com enzima Eco RI, Poço 9: clone 2 positivo de E. coli digerido com enzima Eco RI, Poço 10: clone 3 positivo de E. coli digerido com enzima Eco RI.

\subsubsection{Análise por PCR dos clones de E. coli e Agrobacterium.}

A Figura 5 ilustra o resultado do PCR de colônias que confirmou que os clones obtidos tanto de E. coli como de Agrobacterium tumefaciens que amplificaram um fragmento de $2020 \mathrm{pb}$ que corresponde ao gene da esfingomielinase presente no vetor.pC3300GCHI.Sphingo.

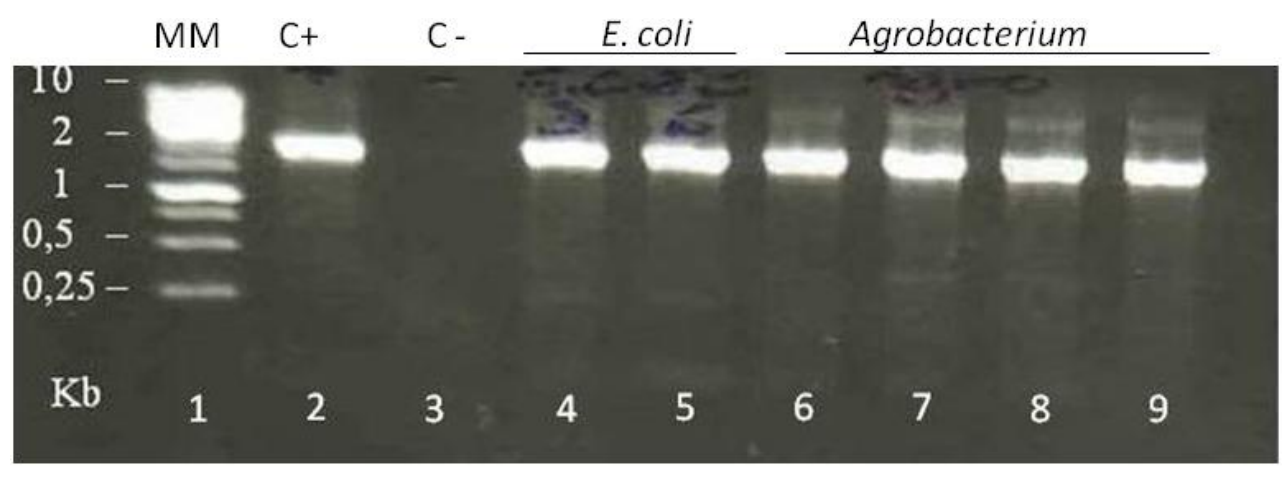

Figura 5: Gel de agarose $(1 \%)$ da análise por PCR dos clones transformantes. Poço1: marcador de massa molecular $1 \mathrm{~kb}$ Ladder (Invitrogen), poço 2: controle positivo, poço 3: controle negativo, poço 4-5: clone de E. coli, poço 6-9 clones positivos de Agrobacterium. 


\subsubsection{Transformação genética de plantas de tabaco com o vetor pC3300GCHI.Sphingo}

Após a cocultura sólida, alguns dos explantes transferidos para o meio de regeneração na presença do regulador de crescimento BAP e do agente seletivo glifosinato de amônio desenvolveram gemas axilares (Figura 6A) que posteriormente se multiplicaram (Figura 6B) e formaram brotações (Figura6C). Brotos alongados foram isolados (Figura6D) e cultivados no meio de enraizamento para a formação das primeiras raízes (Figura 6E), dando origem a plântulas (Figura 6F) que foram aclimatadas em casa de vegetação. Trinta e seis (36) plantas regeneradas na presença do herbicida glifosinato de amônio foram aclimatizadas em casa de vegetação, tendo sido submetidas às análises moleculares de PCR e teste de cromatografia de fluxo lateral para a enzima PAT (phosphinotricin acetyl transferase).

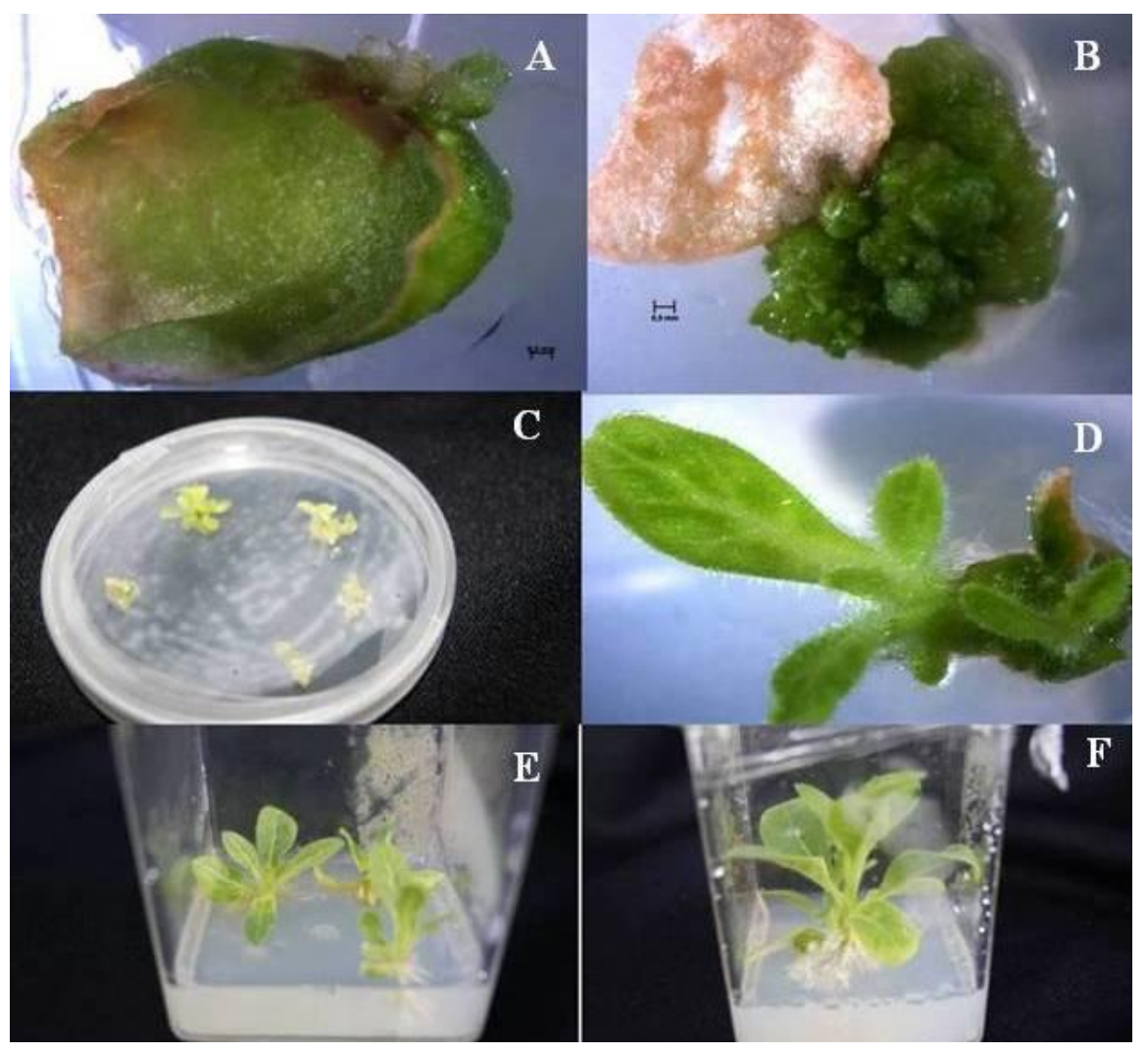

Figura 6. Regeneração de explantes foliares de tabaco após a transformação por Agrobacterium tumefaciens. (A) Explantes um mês após a cocultura com início de regeneração de gemas adventícias, (B) multiplicação de gemas adventícias, (C) elongação de brotos na presença do agente seletivo GA $5 \mathrm{mg} / \mathrm{L}$ e (D) broto isolado em elongação na presença do herbicida GA, (E) brotos alongados transferidos para meio de enraizamento e (F) Plântula de tabaco três meses após a transformação genética. 
De um total de 36 plantas regeneradas 27 foram positivas para a expressão do gene bar detectada pelo Teste GMO TraitCheck (Figura 7) e por PCR, foi detectada a presença do gene da Esfingomielinase

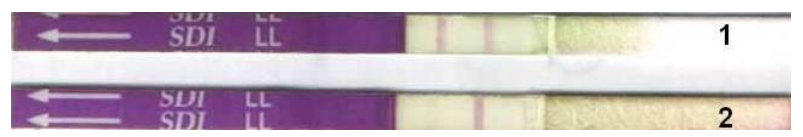

Figura 7. Teste de cromatografia de fluxo lateral realizado com extrato de folhas de tabaco regeneradas na presença do herbicida GA para detecção da proteína PAT. (1) Planta transgênica, a linha inferior denota a presença da proteína PAT. (2) Controle negativo, folha de tabaco não transformado, apenas a linha do controle negativo foi observada.

\subsection{ANÁLISE DA PROGÊNIE}

\subsubsection{Análise da segregação e seleção de plantas $\mathbf{T}_{1}$}

Na Tabela 1 pode ser observado o resultado da aplicação do herbicida glifosinato de amônio nas folhas das linhagens transformadas $\mathrm{T}_{1}, \mathrm{O}$ teste foi utilizado para selecionar linhagens positivas para os bioensaios e para analisar a segregação de cada progênie. As plantas T1 resistentes ao herbicida se desenvolveram normalmente após a aplicação foliar do GA (Figura 8A), enquanto que as plantas T1 susceptíveis e não transgênicas apresentaram necroses nas regiões pinceladas com consequente morte. Com base na resposta de tolerância e suscetibilidade ao herbicida das progênies de cada linhagem foi observada a probabilidade de segregação obtida pelo teste do quiquadrado.

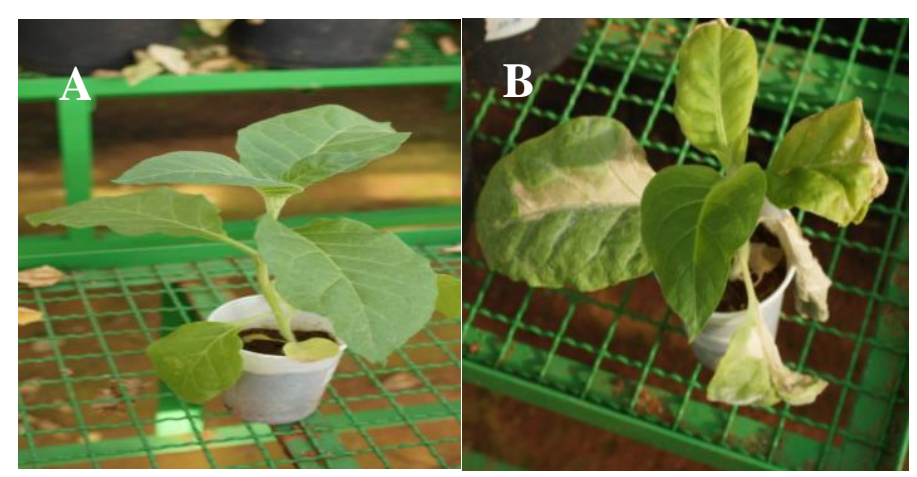

Figura 8: Teste com aplicação do herbicida glifosinato para seleção de progênies transgênicas T1: (8.A) Plantas resistentes ao herbicida não apresentaram lesões, enquanto em (8.B) podemos observar sintomas de necrose na planta susceptível ao herbicida. 
Tabela 1: Análise da segregação das linhagens geneticamente modificadas através da seleção das plantas positivas pela aplicação do herbicida glifosinato de amônio e pela aplicação do teste Qui-quadrado com correção de Yates que calcula a probabilidade de ocorrência de uma ou duas cópias do transgene no genoma. $\chi 2$ : Qui-quadrado, P: Probabilidade.

\begin{tabular}{|c|c|c|c|c|c|c|}
\hline \multirow[t]{2}{*}{ Linhagens } & \multirow[t]{2}{*}{ Plantas Positivas } & \multirow[t]{2}{*}{ Plantas negativas } & \multicolumn{2}{|c|}{ Segregação 3:1 } & \multicolumn{2}{|c|}{ Segregação $15: 1$} \\
\hline & & & $\chi^{2}$ & $\mathrm{P}$ & $\chi^{2}$ & $\mathrm{P}$ \\
\hline 2 & 13 & 2 & 1,48 & 0,3 & 0,51 & 0,25 \\
\hline 2,1 & 13 & 2 & 1,48 & 0,3 & 0,51 & 0,25 \\
\hline 5 & 9 & 6 & 1,48 & 0,17 & 24,40 & 0,0 \\
\hline 6 & 12 & 3 & 0,42 & 0,65 & 3,07 & 0,02 \\
\hline 7 & 9 & 6 & 1,48 & 0,17 & 24,40 & 0,0 \\
\hline 8 & 13 & 2 & 1,48 & 0,3 & 0,51 & 0,25 \\
\hline 10 & 13 & 2 & 1,48 & 0,3 & 0,51 & 0,25 \\
\hline 11 & 13 & 2 & 1,48 & 0,3 & 0,51 & 0,25 \\
\hline 12 & 10 & 5 & 0,42 & 0,45 & 15,01 & 0 \\
\hline
\end{tabular}

A análise por PCR das progênies T1 detectou a presença do gene da Esfingomielinase em nove (9) das dez linhagens analisadas (Figura 9). A linhagem Sphingo.1 não foi tolerante ao herbicida glifosinato de amônio quando este foi aplicado nas folhas, não tendo sido detectada a presença do gene da esfingomielinase em nenhuma progênie desta linhagem. Assim sendo, esta linhagem foi considerada um escape e foi mantida como controle negativo das plantas transformadas. 


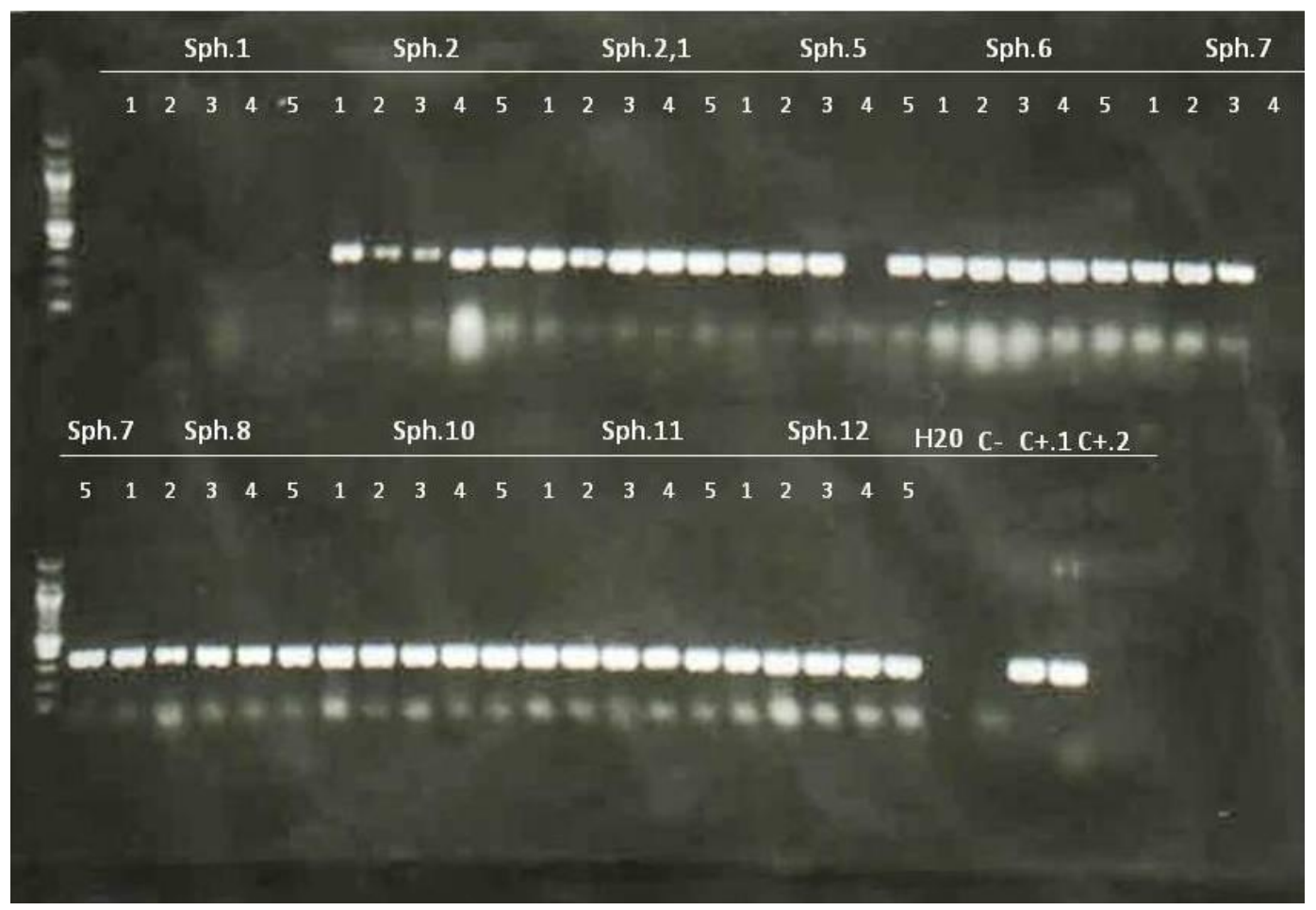

Figura 9: Gel de agarose (2\%) do PCR de cinco plantas (números de 1 a 5) das 15 plantas T1 testadas de cada linhagem de Tabaco transformadas com o vetor pC3300GCHI.Sphingo utilizadas nos bioensaios, $\mathrm{Sph}=$ Sphingo, seguido do número da linhagem. MM $100 \mathrm{pb}$ : marcador de massa molecular $100 \mathrm{bp}$ Ladder (Invitrogen); Sph.1 a Sph.12: Linhagem (1) onde os números de 1 a 5 refere-se ao DNA extraído de 5 progênies de cada linhagem. $\mathrm{H}_{2} 0$ : Água, $\mathrm{C}$-: Planta não transformada, $\mathrm{C}+1$ : Clone de $E$. coli com o vetor Pc3300.Sphingo, C+.2: vetor Pc3300.Sphingo.

\subsubsection{Desafio de Folhas destacadas utilizando discos de micélio de $S$.}

\section{Scletoriorum}

Cinco plantas de cada linhagem previamente confirmadas foram utilizadas no ensaio da folha destacada inoculada com o fungo $S$. scletotiorum. As repetições do teste com o fungo $S$. scletotiorum demonstraram que as linhagens transgênicas não diferiram significativamente com relação ao controle (Figura 10). 


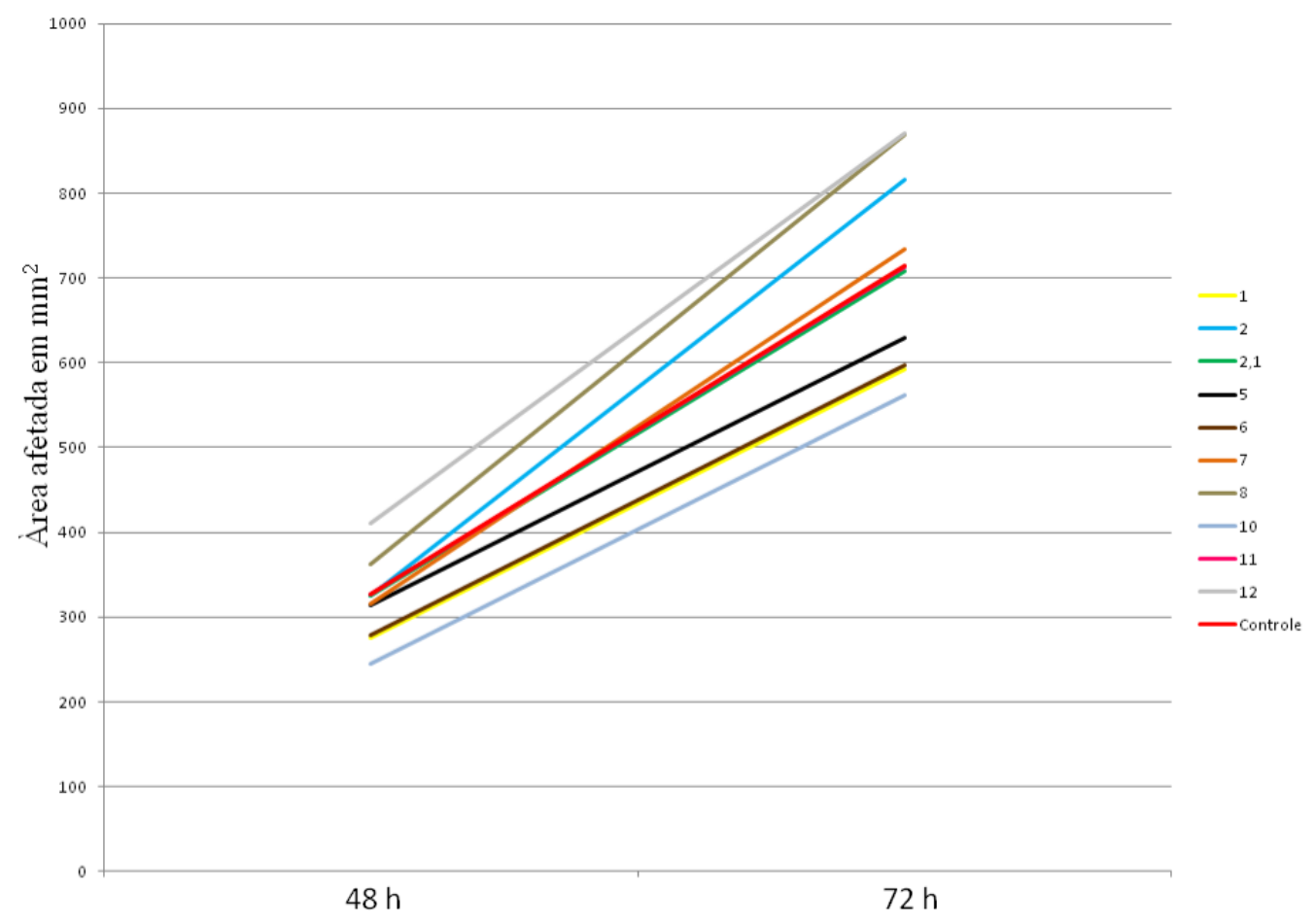

Figura 10: Curva de progresso da doença obtida a partir da média das áreas lesionadas (duas repetições) após a inoculação de folhas destacadas com discos de micélio do fungo S. sclerotiorum. A área infectada foi medida em milímetros 48 e 72 horas após a inoculação, $\mathrm{n}=5$.

Na primeira repetição após 48 horas da inoculação já era possível observar os primeiros sintomas de doença em todas as plantas testadas, contudo a análise do progresso da doença revela que os eventos transgênicos apresentaram atraso no desenvolvimento dos sintomas quando comparado com o controle não transgênico. Após 72 horas, com a evolução dos sintomas em alguns eventos transgênicos foi observado que a área lesionada do controle foi mais drástica que os eventos transgênicos. As áreas lesionadas dentro dos eventos transgênicos apresentaram uma lesão menor quando comparadas com o controle. Podem ser destacadas as linhagens 5, 6 e 10 que não possuíam diferenças significativas entre as progênies e melhores resultados em comparação com as plantas não transgênicas (Figura 11).

$\mathrm{Na}$ segunda repetição as lesões observadas nas plantas transgênicas após 48 horas não diferiram dos eventos controle. Foi observado com o progresso da doença que a área lesionada nos eventos transgênicos foi maior do que o controle, estas atingiram as bordas e se estenderam por quase toda a folha, não demonstrando a relação entre a 
expressão do gene da esfingomielinase com a tolerância ao fitopatógeno, as linhagens 6 e 10 foram as que apresentaram resultados semelhantes ao controle não transgênico.

$\mathrm{Na}$ terceira repetição do ensaio com o fungo e a folha destacada todos os eventos analisados possuíam uma menor área lesionada com relação às outras repetições, contudo a partir de 48 horas já era possível observar uma diferença entre os eventos transgênicos e controle, onde apenas algumas progênies da linhagem 5 destoavam do restante das plantas analisadas. Vale ressaltar que mesmo que não tenha sido observada total inibição dos sintomas nas plantas positivas a partir de $72 \mathrm{~h}$ pode ser observado menores índices de severidade.

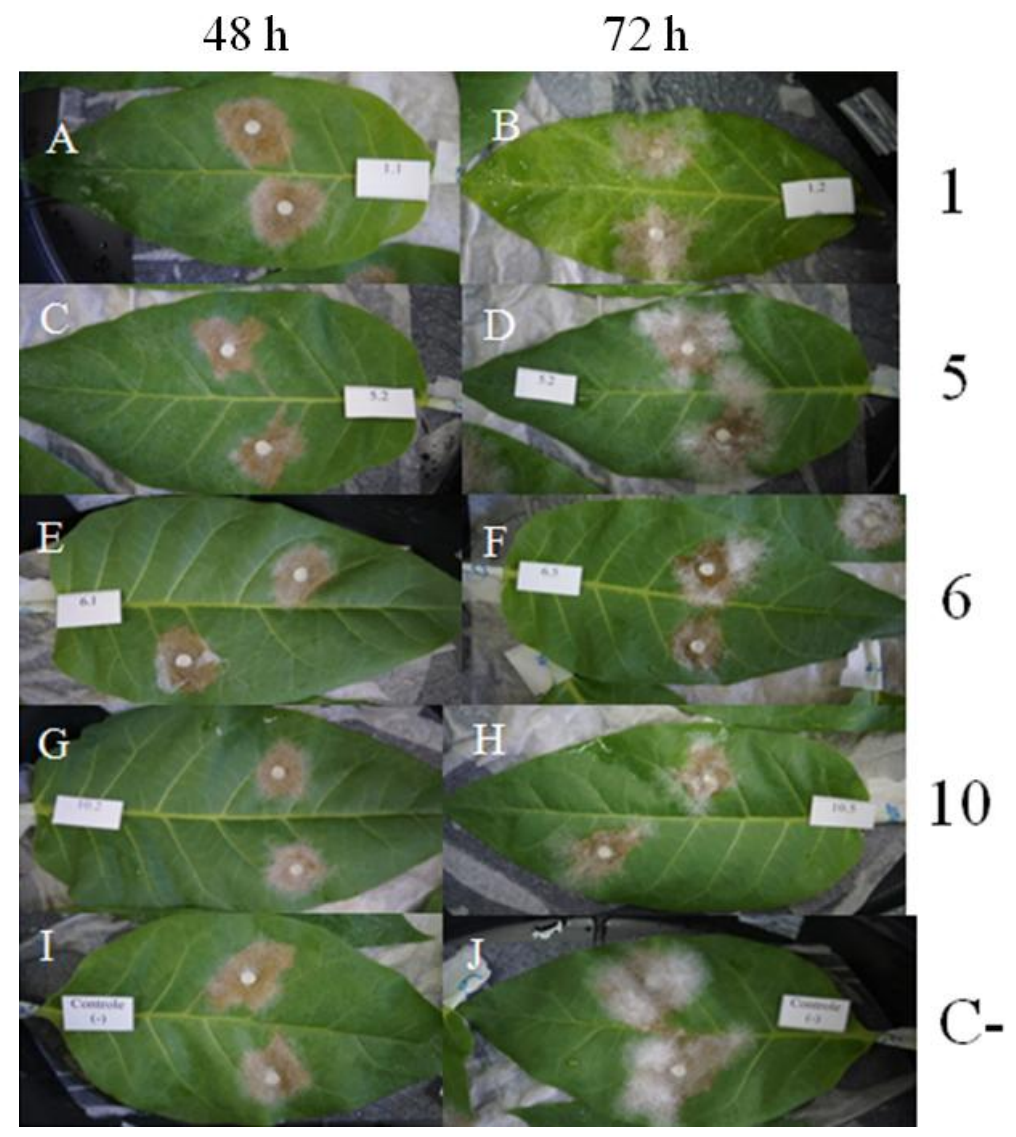

Figura 11 - Resposta de folhas destacadas a S. sclerotiorum obtida pela inoculação com discos de micélio. 1) Folhas do evento Sphingo 1 não transgênico após 48 horas(A) e 72 horas (B); 5) Folhas do evento Sphingo 5 transgênico após 48(C), 72(D); 6) Folhas do evento Sphingo 6 transgênico após 48(E), 72(F); 10) Folhas do evento Sphingo 10 transgênico após 48(G), 72(H); C -) Folhas do controle negativo após 48(I), 72(J) . 
A análise estatística utilizando ANOVA não paramétrica (Kruskal-Wallis) demonstrou que houve diferença significativa nos valores obtidos entre as repetições (Figura 12). Quando comparada a repetição 1 com a 2 não existe diferença estatística, entretanto estas repetições diferem da repetição 3.

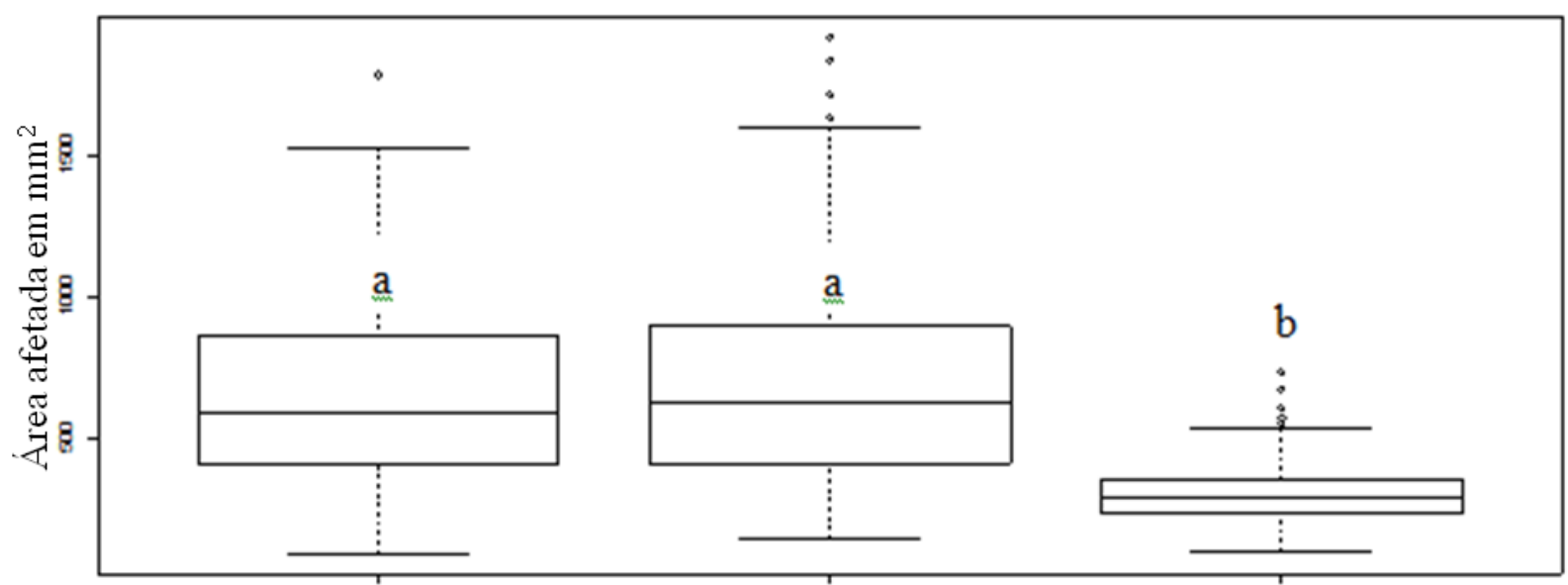

Figura 12: Área afetada nas três repetições experimentais. Letras iguais mostram que as repetições são iguais segundo o teste não paramétrico de (Kruskal-Wallis $=116,1609$, p-valor $<0,001)$

Como as repetições experimentais não foram homogêneas decidiu-se analisar as repetições separadamente da repetição 3 (Figura 13). Nesta comparação as linhagens não tiveram diferenças em relação ao controle (Figura 14) e a análise estatística entre as linhagens demonstra que elas não apresentam diferenças estatísticas entre si quanto à área afetada $\left(\mathrm{F}_{10,209}=1.04, \mathrm{p}-\mathrm{valor}=0,411\right)($ Figura 15). 


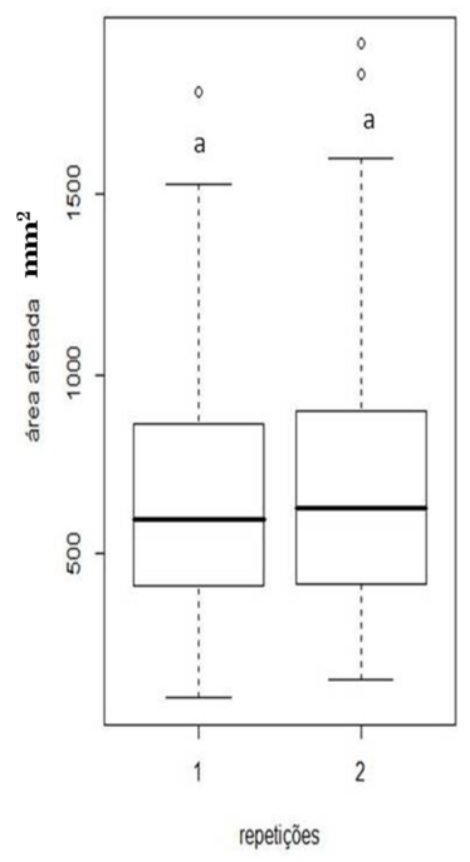

Figura 13: Análise de variância utilizando o teste ANOVA não paramétrico entre as repetições. Letras iguais mostram que as repetições são iguais segundo o teste não paramétrico de (Kruskal-Wallis $=0,6143$, p-valor $<0,43$ )

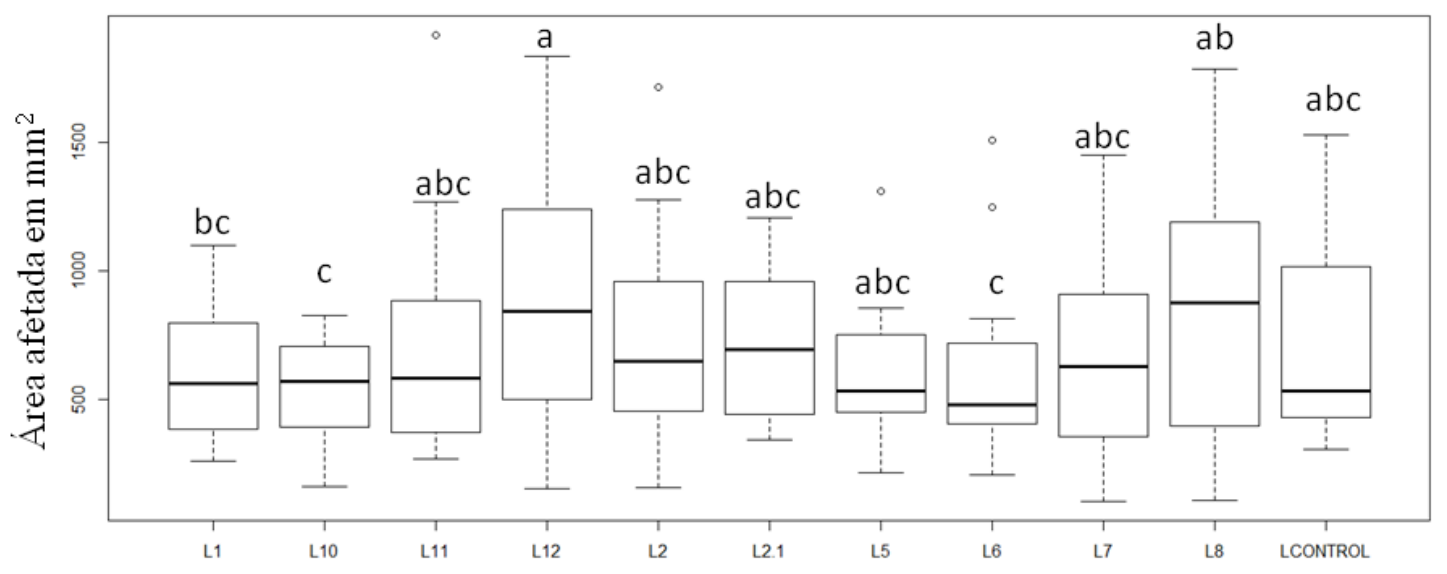

Figura 14. Área afetada das linhagens amostradas nas repetições experimentais. Letras iguais mostram que as linhagens são iguais segundo o teste não paramétrico de (Kruskal-Wallis $=13.11$, $\mathrm{p}$-valor $<0.21$ ) 


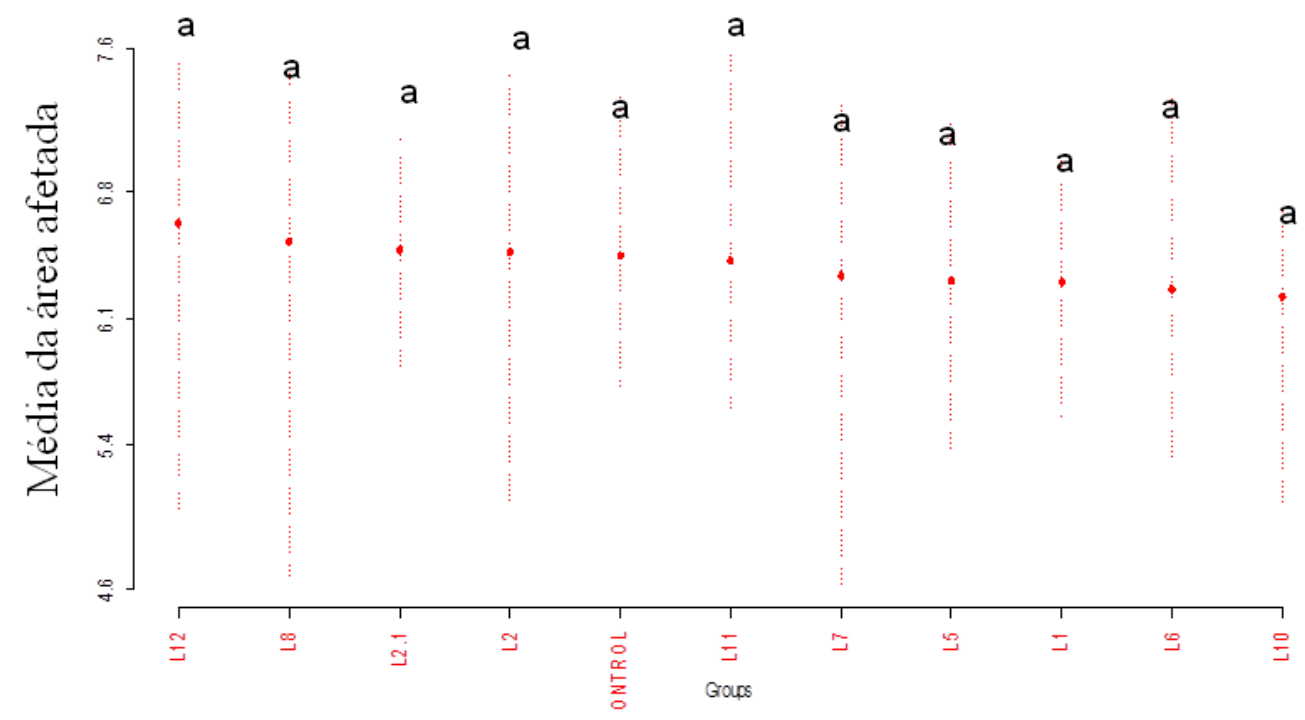

Figura 15. Distribuição em grupo das linhagens na ordem decrescente das médias. Letras/Cores iguais mostram que as repetições são iguais segundo o teste Scott Knott à $5 \%$ de significância.

Observando os dados brutos, pode-se destacar como as melhores plantas analisadas individualmente destacamos 2.2, 5.5, 6.2, 6.3, 6.5, 8.1, 10.1, 10.5, 11.1, 11.2 e 11.3, essas progênies apresentaram sempre menor área de lesão comparada às plantas controle e menores desvios entre as repetições.

\subsubsection{Infiltração com Pseudomonas syringae pv. tabaci}

A avaliação do bioensaio com infiltração bacteriana (Figura 16) utilizando o clorofilômetro foi realizada em 6 pontos com a suspensão bacteriana e um ponto com água, esta análise demonstrou que as plantas controle possuem duas vezes menos clorofila nas áreas infiltradas do que as plantas transgênicas, e a leitura da área infiltrada demonstrou que houve diferença nas áreas lesionadas entre os eventos geneticamente modificados e o controle. 


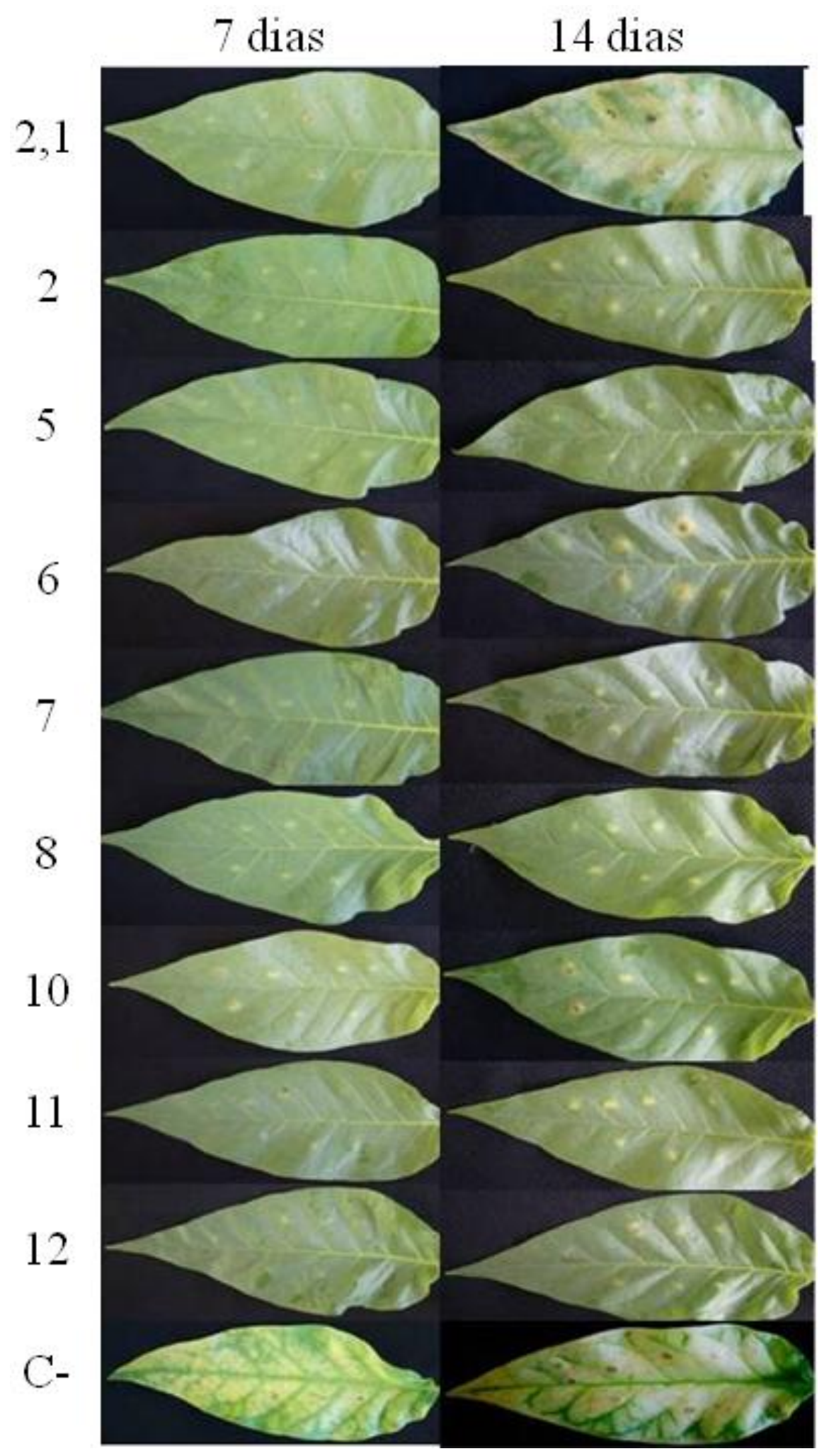

Figura 16: Bioensaio com a bactéria Pseudomonas pv tabaci. Resposta de folhas destacadas a infiltração da suspensão bacteriana após 7 e 14 dias de infiltração. 1) Folha do evento Sphingo 1 não transgênico; C -) Folhas do controle negativo; 2-12 Folhas dos eventos transgênicos após 7 e 14 dias de infiltração 
No primeiro ensaio, sete dias após a infiltração já era possível verificar o início do crescimento da área afetada, com consequente perda de clorofila. Podia-se observar ao redor do local de infiltração um crescimento da área lesionada com uma diferença em até duas vezes entre os eventos transgênicos e controle. Com o progresso da doença após 14 dias, foi observado 1: Um aumento nas lesões nas plantas susceptíveis, o que não foi observado nas plantas tolerantes, 2: Maiores perdas de clorofila em torno da área de infiltração 3: Infiltração bacteriana nas plantas controle tomando praticamente toda a folha enquanto nas plantas transformada foi observada uma reação para controle do crescimento bacteriano. Neste experimento a leitura da área lesionada (Figura 17.A,C).indicou uma grande diferença entre as plantas transformadas em relação ao controle, e ainda a análise do experimento com auxilio do clorofilômetro demonstrou que as plantas controle tiveram grandes perdas nas áreas infectadas

A análise do segundo ensaio de infiltração bacteriana através das medidas da área confirmou os resultados já obtidos, as plantas controle possuíam uma área lesionada muito superior aos eventos transgênicos (Figura 17.B,D).
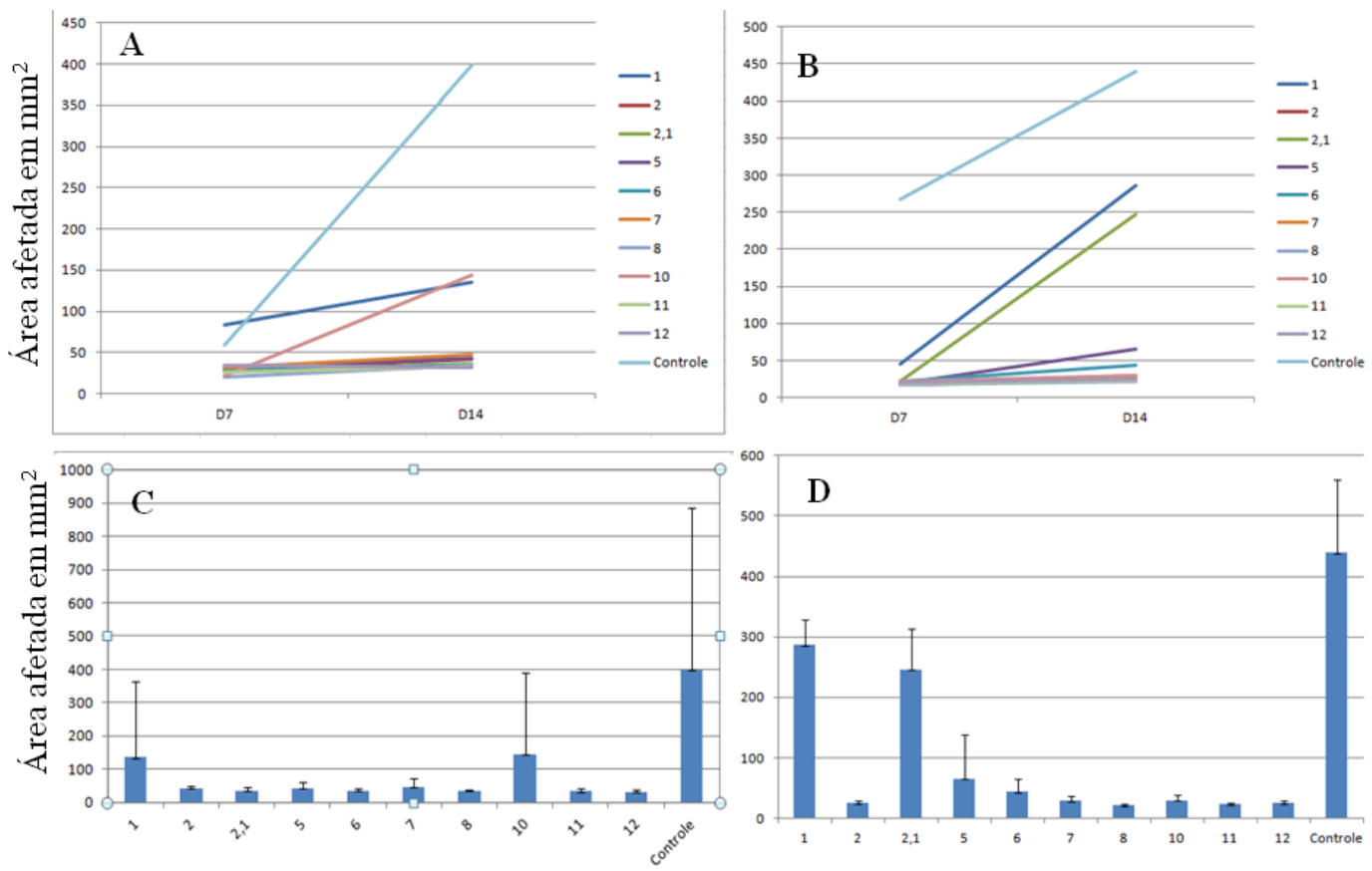

Figura 17: Gráfico das áreas lesionadas nas duas repetições após a inoculação de folhas destacadas com a bactéria $P$. syringae. A e B: Curva de progresso da doença obtida a partir da média das progênies. C e D: Gráfico em barras com os valores médios de área infiltrada obtidos para cada linhagem após 14 dias de ensaio, A-B: gráficos da $1^{\circ}$ repetição, C-D: gráficos da $2^{\circ}$ repetição 
A análise estatística utilizando o teste ANOVA para dados não paramétricos demonstra que à 5\% de significância não houve diferença entre as áreas afetadas nas duas repetições (Figura 18), ainda o teste de comparação entre as médias indica que as médias são iguais

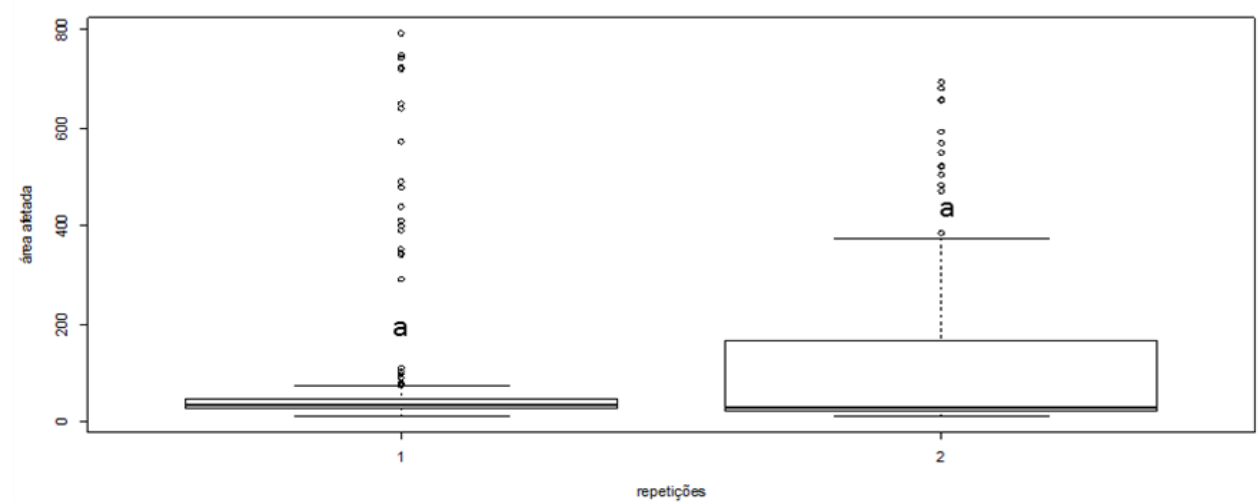

Figura 18: Média das áreas lesionadas obtidas com a infiltração de Pseudomonas syringae nas duas repetições. As letras iguais mostram que as repetições são iguais segundo o teste não paramétrico de Kruskal-Wallis $=2.978$, p-valor= 0,084)

As análises estatísticas destacaram a linhagem transgênica $(2,1)$ destoando das demais linhagens geneticamente modificadas. $\mathrm{O}$ teste de comparação das médias indica que as médias entre as linhagens são diferentes entre si e em comparação aos controles (Figura 19), a distribuição em grupos pelo teste de Scott Knott (Figura 20) demonstra que as linhagens transgênicas são distribuídas inferiores aos controles $\left(\mathrm{F}_{10,649}=7.17\right.$,pvalor $<0,001)$.

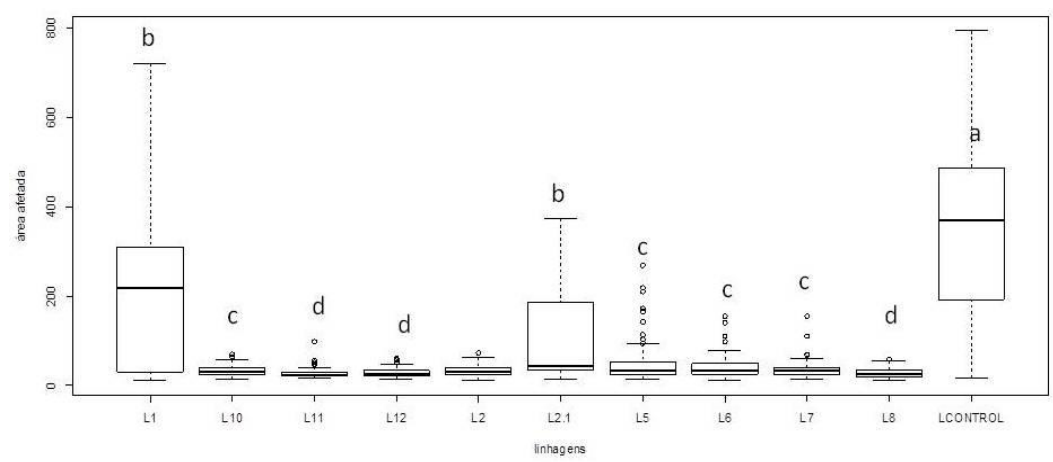

Figura 19: Média das áreas lesionadas obtidas com a infiltração de Pseudomonas syringae para cada linhagem. As letras iguais mostram que as linhagens são iguais segundo o teste não paramétrico de Kruskal-Wallis $=222,42$, p-valor $<0,001$ 


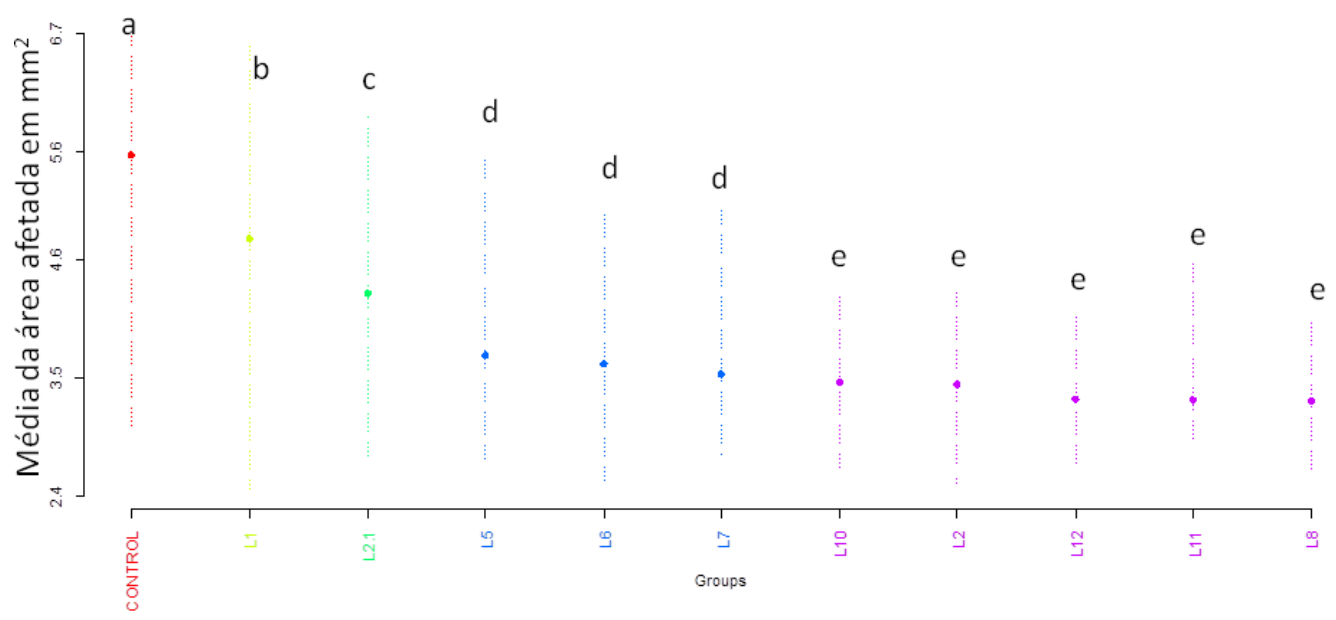

Figura 20. Distribuição em grupos das linhagens amostradas nas repetições experimentais. Cores iguais mostram que as repetições são iguais segundo o teste Scott Knott à 5\% de significância.

Analisando a variação isolada das progênies nas duas repetições destaca-se (2,2; $5.1 ; 6.2 ; 6.3 ; 10.211 .1$ e 11.2) como as melhores progênies, estas foram plantas que apresentaram uma área lesionada em torno de 25 a $50 \mathrm{~mm}^{2}$ quando comparadas com o controle que variou de 150 à $615 \mathrm{~mm}^{2}$.

A leitura com o clorofilômetro permitiu quantificar as perdas de clorofila observadas pela infecção bacteriana. A leitura da clorofila de cada folha permitiu realizar um acompanhamento nas perdas naturais de clorofila (Figura 21), comparar com as áreas infiltradas no ensaio e observar a variação entre o ponto infiltrado somente com água e os pontos infiltrados com a suspensão bacteriana.

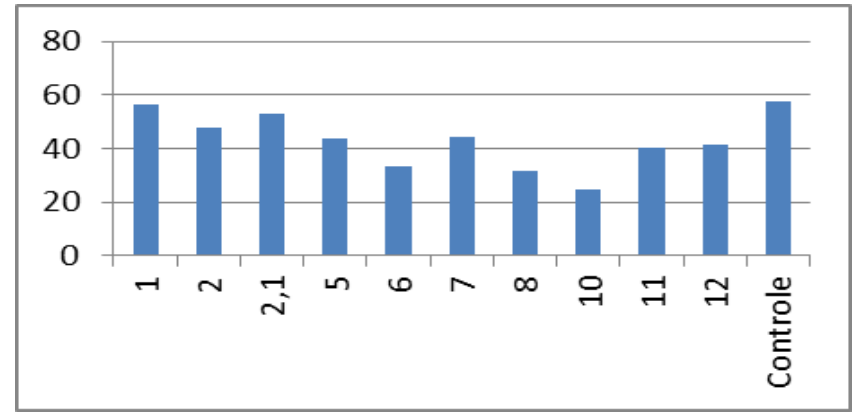

Figura 21: Perdas de clorofila que ocorrem naturalmente nas folhas das linhagens após 14 dias de ensaio. 
Todas as análises levaram em consideração os valores de um ponto sem infiltração. As infiltrações com água permitiram observar que nestas áreas não ocorrem perdas além do natural ou devida à lesão causada pelo processo de infiltração.

A análise de perdas da clorofila mostrou que as linhagens transgênicas tiveram menores infiltrações que o controle nas duas repetições. Na primeira repetição foram observadas perdas significativamente maiores nas plantas não transformadas (Figura 22, A), contudo na segunda repetição foram observadas perdas na mesma proporção entre o controle e as plantas transgênicas (Figura 22, B). Isto ocorreu devido à metodologia estabelecida para a leitura que levava apenas em consideração três pontos ao redor do halo de infecção não abrangendo a folha por completo.

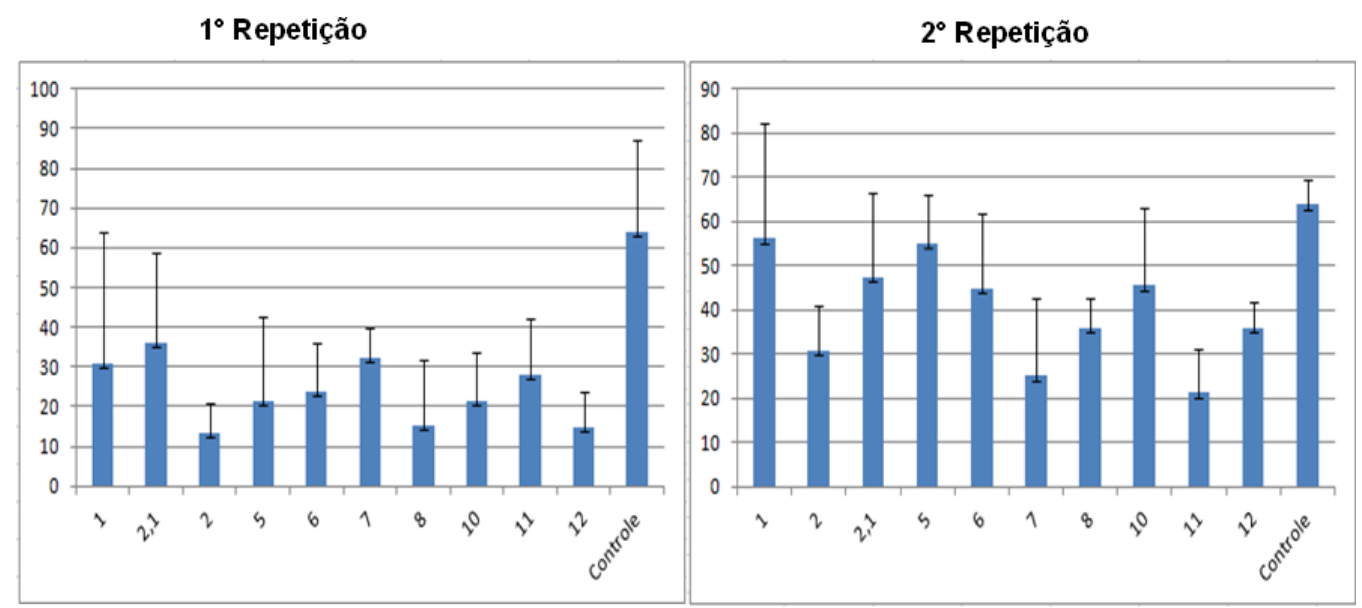

Figura 22. Gráfico das porcentagens de perdas de clorofila nas regiões infiltradas com a bactéria $P$. syringae nas duas repetições experimentais.

\subsubsection{Recuperação e identificação das bactérias}

A recuperação da infiltração bacteriana com os meios de cultivos semi seletivos permitiu comprovar que os sintomas observados eram causados pela bactéria $\mathrm{P}$. syringae. No meio SPA as colônias apresentavam o centro vermelho e bordas brancas, e no meio de cultivo MSP estirpes jovens amareladas que se tornam laranja à medida que se formava a colônia. 


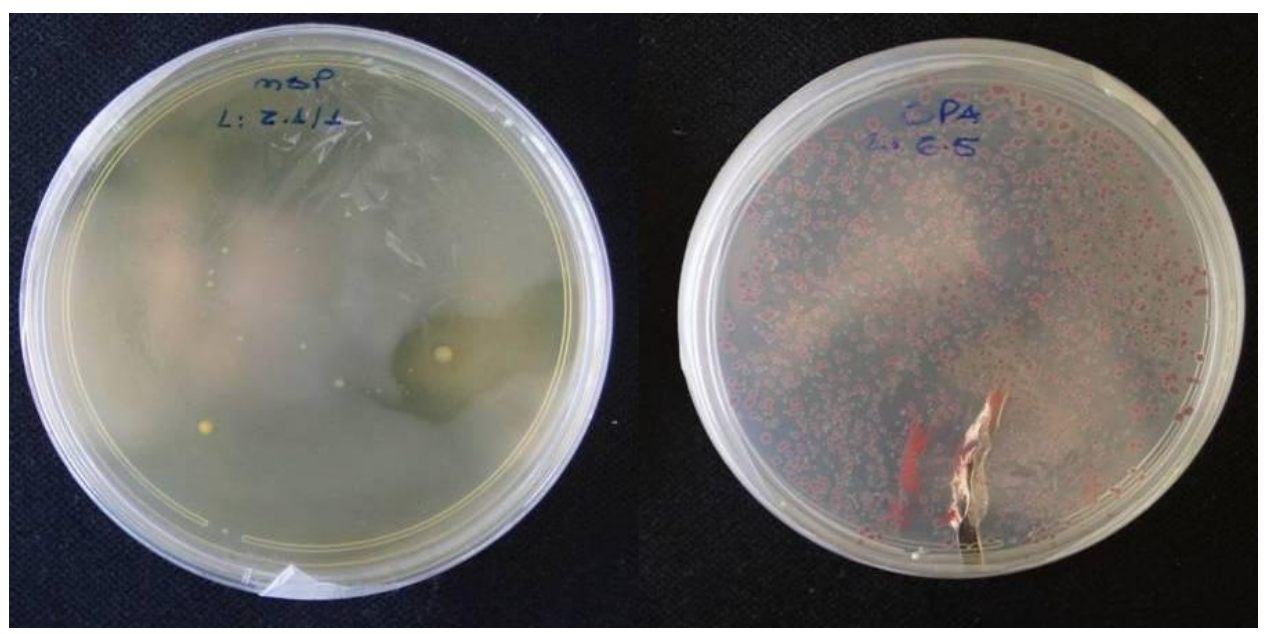

Figura 23: Meios de cultivo semi seletivos MSP e SPA contendo colônias de $P$. syringae recuperada das folhas infiltradas no bioensaio. 


\section{DISCUSSÃO}

Na busca por genes candidatos que podem levar plantas a apresentar resistência a fungos, em geral encontramos genes que codificam enzimas hidrolíticas, glucanases e quitinases, cuja função está relacionada com a capacidade de perturbar e lisar a parede celular, inibindo assim o crescimento e a propagação de hifas sobre tecidos vegetais (ISLAM, 2006 \& GROVER et al. 2003, KHALILUEV \& SHPAKOVSKII, 2013). Esse trabalho demonstrou que plantas modificadas para expressar o gene sintético de uma esfingomielinase de Trichoderma virens mostraram resistência a uma bactéria (Pseudomonas syringae), mas não a um fungo (Sclerotinia sclerotiorum). Esta diferença deve estar relacionada com o contato da proteína com as estruturas membranares e ciclo de vida destes patógenos.

Diversos trabalhos têm encontrado a resistência a fungos utilizando o gene de quitinase (CEASAR \& IGNACIMUTHU, 2012). Nestes trabalhos publicados as quitinases estão envolvidas na remodelação e degradação da parede celular de outras espécies de fungos. Baranski et al. (2008) transformou cenoura com Chit36 de Trichoderma harzianum e observou um aumento na tolerância a Alternaria radicina e Botrytis cinérea, BOLAR et al. (2000) transformou maça e observou resistência a Venturia inaequalis, concomitantemente, Dana (2006) transformou tabaco com uma combinação de duas quitinases CHIT33 e CHIT42 sobre o controle de um peptídeo de sinal direcionado para o apoplasto e observou além de uma tolerância aos patógenos Rhizoctonia solani e Pseudomonas syringae uma tolerância a estresses de sal e de metais pesados.

A expressão de glucanases também tem sido alvo de estudos. Singh et al. (2014) demonstraram o envolvimento desta enzima na defesa da planta através da hidrólise de glucano, componente essencial da parede celular, na resposta de defesa contra os fungos patogênicos.

Os resultados obtidos dos desafios demonstraram que as plantas transformadas não diferem das selvagens na resposta ao fungo Sclerotinia sclerotiorum. Estes resultados são diferentes dos encontrados por (SHAH, 2010) que utilizou o extrato de 
uma planta de tomate expressando uma quitinase de Trichoderma Virens, e observou uma tolerância a Sclerotinia, diferente de Cunha et al. (2010) que obtiveram sucesso no controle de Sclerotinia utilizando o gene da oxalato descarboxilase em plantas de soja geneticamente modificado, e Rustagi (2014) que expressou um peptídio antimicrobiano quimérico de cecropin A e observou em mostarda Brassica juncea significativa resistência a $S$. sclerotiorum, desde o controle na expansão do micélio até a redução das lesões e dos escleródios formados no interior do caule.

A expressão do gene da esfingomielinase neste trabalho não se mostrou eficaz para inibir o crescimento fúngico, mas sim bacteriano. É possível que isso esteja relacionado a sua apresentação às estruturas membranares desses patógenos quando no contato com as plantas. Sclerotinia sclerotiorum é fungo necrotrófico muito agressivo que que interage com os tecidos vivos por um período muito curto de tempo. Possivelmente esse período não é suficiente para que o efeito da presença da esfingomielinase sobre as estruturas membranares do patógenos seja efetivo. Na cinética dos genes expressos por Trichoderma harzianum em contato com $S$. sclerotiorum proposto por Troian et al., (2014) quitinase, glucanases e proteases tiveram sua expressão durante a interação com S. scleroiorum, é provável que após a sua atuação na parede celular a enzima esfingomielinase possa interagir com a membrana.

Dentre uma das principais estratégias que vêm sendo utilizadas na busca de resistência a doenças causadas por bactérias, envolvem a introdução genes exógenos codificando peptídeos antimicrobianos resultando numa desestabilização da membrana plasmática dos patógenos (ZASLOFF, 2002; PAOLI et AL 2007, BOSCARIOL et al. 2006, CARDOSO et al. 2010).

Os peptídeos antimicrobianos atuam na degradação da parede celular dos fungos e na permeabilização da membrana (WALLY \& PUNJA, 2010). As defensinas são uma classe de peptídeos antimicrobianos de plantas que possuem atividade antimicrobiana através da interação com esfingolipídeos da membrana (THEVISSEN et al., 2003). As esfingomielinases são enzimas que catalisam a hidrolise da esfingomielina, alterando e desestabilizando a conformação da membrana plasmática (DIAS LOPES, 2013; BINFORD, 2005, MILHAS et al. 2010). 
O teste com a bactéria Pseudomonas syringae pv. tabaci objetivou verificar a resposta do gene da esfingomielinase a outro fitopatógeno conhecido de tabaco. A bactéria Pseudomonas sp. uma bactéria Gram-negativa que possui esfingolipídios como componente da membrana plasmática.

Os resultados apresentados indicam que a expressão constitutiva do gene da esfingomielinase desencadeia uma resistência a Pseudomonas syringae, resultado similar foi observado por (CARMONA et al. 1993) com a expressão de uma classe de peptídeo antimicrobiano $\alpha$-Tionina onde verificou o aumento na resistência a Pseudomonas syringae. Neste trabalho as plantas controle apresentavam manchas cloróticas e lesões necróticas ao redor do ponto de infecção, sintomas similares foram observados em nosso trabalho nas plantas susceptíveis.

$\mathrm{Na}$ literatura várias classes de peptídeos antimicrobianos têm sido estudadas, os trabalhos utilizando Cecropin B que afetam as forma dos poros nas membranas de bactérias mostram resultados contraditórios, enquanto Jaynes et al., (1993) transformaram tabaco e observaram resistência a Pseudomonas solanacearum, Hightower et. al. (1994) não encontrou diferença na resposta de plantas expressam Cecropina, tantos as plantas transformadas quantos as plantas controle apresentavam sintomas parecidos, manchas necróticas, surgimento de um anel e manchas cloróticas espalhadas pelas folha além de morte das células infectadas e Huang et. al. (1997) utilizando uma cecropina MB39 observou que somente com concentrações mais altas de inoculo da bactéria ocorreu necrose nas áreas infiltradas. Esta necrose era claramente visível nas plantas não transformadas, os autores citam a ausência de desenvolvimento de sintomas associada com a supressão do crescimento bacteriano, e ainda propõem a utilização deste gene no controle de doenças de plantas.

O resultado apresentado pelo gene da esfingomielinase, expressa no citoplasma, mostrou uma atividade bactericida semelhante a outros trabalhos que expressaram peptídeos antimicrobianos. No entanto é possível que resultados ainda mais interessantes pudessem ser obtidos se a esfingomielinase fosse endereçada para o apoplasto. Fukuta et al., (2012) expressando um peptídeo antimicrobiano (Lactoferricina B) associado a um peptídeo de sinal direcionado para o apoplasto, desenvolveu plantas de tabaco mostrando alta resistência contra Pseudomonas syringae. 
Pode-se imaginar que o endereçamento da esfingomielinase para o apoplasto pode melhorar a contato proteína-patógeno, aumentando sua atividade como degradadora da estrutura da membrana. A esfingomielinase ácida possui seu ótimo de atividade em ph ácido, assim esta enzima poderá ser mais ativa no apoplasto onde o ph é ácido e ainda poderá atuar antes do contato do patógeno com o meio intracelular.

Osusky (2000) utilizando um gene sintético cecropin-melitina (MsrAl) com uma modificação $\mathrm{N}$ terminal, aumentou fortemente a resistência das plantas de batata à infecção bacteriana (Erwinia sp.) e por fungos (Fusarium, Phytophthora sp.) os autores afirmam ainda que as cargas positivas na parte hidrófila do peptídeo são essenciais para atividade antifúngica.

Outra estratégia diferente que têm sido proposta para o controle de doenças bacterianas foi a proposta por $($ GER, 2002) que utilizou a expressão de proteínas ligada a reação de hipersensibilidade (HARP) contra Pseudomonas syringae pv. tabaci e Erwinia carotovora subs. carotovora, e apesar de observar que a resposta de hipersensibilidade não ocorre de forma constitutiva, os autores sugerem que a resistência apresentada pelas plantas transgênicas são devidas a resposta de hipersensibilidade nas áreas de infiltração.

A recuperação da bactéria das folhas infiltradas possibilitou identificar o agente patógenico, seguindo o postulado de Koch e o re-isolamento em meio semi seletivo MSP comprovou-se que a bactéria Pseudomonas syringae pv; tabaci era responsável pela lesão observada, pois Stefanova, (2009) utilizando uma modificação nos antibióticos do meio MSP para aperfeiçoar a recuperação de colônias de Pseudomonas syringae pv tabaci descreveu uma morfologia semelhante das colônias identificadas. 


\section{CONCLUSÃO}

As plantas transgênicas de tabaco com o vetor pC3300. Sphingo contendo o gene da esfingomielinase de Trichoderma demonstraram resistência a Pseudomonas syringae pv. tabaci, entretanto não foi observado resistência em relação a Sclerotinia sclerotiorum. As plantas obtidas se mostraram fenotipicamente similares às plantas não modificadas, mostrando que o gene esfingomielinase parece não causar qualquer problema para o desenvolvimento, florescimento e produção de frutos e sementes. Este estudo abre nova perspectiva para o desenvolvimento de uma estratégia para controlar doenças causadas por infecções bacterianas. 


\section{PERSPECTIVAS}

Na continuação desse trabalho propõe-se:

- Avaliar por RT-PCR o acúmulo do transcrito do gene da esfingomielinase.

- Fazer uma análise de Western blot e ELISA para a quantificação da proteína de interesse na progênie

- Realizar bioensaios para avaliação de resistência das plantas a outras bactérias fitopatogênicas, tais como Erwinia carotovora, Xanthomonas campestri e Xylella fastidiosa.

- Inserir o gene da esfingomielinase em culturas de interesse econômico e avaliar o desempenho dos transformantes. 


\section{REFERÊNCIAS BIBLIOGRÁFICAS}

ADAMS, M. D.; KELlEY, J. M.; GOCAYNE, J. D.; DUBNICK, M.; POLYMEROPOULOS, M. H.; XIAO, H.; MERRIL, C. R.; WU, A.; OLDE, B.; MORENO, R. F.; KERLAVAGE, A. R.; MCCOMBIE, W. R.; VENTER, V. C. Complementary DNA sequencing: expressed sequence tags and human genome project. Science, 252:1651-1656, 1991.

APG. An update of the Angiosperm Phylogeny Group classification for the orders and families of flowering plants: APG III. Botanical Journal of the Linnean Society, 161, 105-121, 2009.

BAILEY, B.A.; BAE H.; STREM, M. D.; ROBERTS, D. P.; THOMAS S. E.Fungal and plant gene expression during the colonization of cacao seedlings by endophytic isolates of four Trichoderma species. Planta, 224:1449-1464, 2006.

BARANSKI, R. KLOCKE, E.; NOTHNAGEL, T. Chitinase CHIT36 from Trichoderma harzianum enhances resistance of transgenic carrot to fungal pathogens. Journal Phytopathology, 156: 513-521, 2008

BETTIOL, W.; MORANDI, M. A. B. Controle biológico de plantas in: BETTIOL, W., MORANDI, M. A. B. Biocontrole de doenças: uso e perspectivas plantas. Jaguariuna: Embrapa Meio ambiente, 2009. 341p.

BENÍTEZ, T.; RINCÓN, A. M.; LIMÓN, M. C. CODÓN, A. C. Biocontrol mechanisms of Trichoderma strains. International microbiology, 7:249-260, 2004.

BIEBERICH, E. Integration of glycosphingolipid metabolism and cell-fate decisions in cancer and stem cells: review and hypothesis. Glycoconjugate Jornal 21:315-327, 2004

BINFORD, G. J.; CORDES, M. H. J.; WELLS, M. A. Sphingomyelinase D from venoms of Loxosceles spiders: evolutionary insights from cDNA sequences and gene structure. Toxicon, 45:547-560, 2005.

BOLAR, J. P.; NORELLI, J. L.; WONG, K.-W.; HAYES, C. K.; HARMAN, G. E.; ALDWINCKLE, H. S. Expression of endoquitinase from Trichoderma harzianum in transgenic apple increases resistance to apple scab and reduces vigor. Phytopathology 90:72-77, 2000.

BOSCARIOL, R. L.; MONTEIRO, M.; TAKAHASHI, E. K.; CHABREGAS, S. M.; VIEIRA, M. L. C.; VIEIRA, L. G. E.; PEREIRA, L. F. P.; MOURÃO FILHO, F. A. A.; CARDOSO, S. C.; CHRISTIANO, R. S. C. Attacin A gene from Tricloplusia ni reduces susceptibility to Xanthomonas axonopodis pv. citri in transgenic Citrus sinensis 'Hamlin'. Journal of the American Society for Horticultural Science 131: 530-536. 2006 
BRANTS, A.; EARLE, E. D. Transgenic tobacco cell cultures expressing a Trichoderma harzianum endoquitinase gene release the enzyme into the medium. Plant Cell Report, 20:73-78, 2001.

BRASILEIRO, A. C. M.; DUSI, D. M. A. Transformação genética de plantas. In: TORRES, A. C.; CALDAS, L. S.: BUSO, J. A. Cultura de tecidos e transformação genética de plantas. Embrapa, Brasília, 2002.

BROGUE, K.; CHET, I.; HOLLIDAY, M,; CRESSMAN, R.; BIDDLE, P.; KNOWLTON, S.; MAUVAIS, J.; BROGUE, R. Transgenis plants with enhanced resistance to the fungal pathogen Rhizoctonia solani. Science: 254: 1194-1197, 1991

BROTMAN, Y.; KAPUGANTI, J. G.; VITERBO, A. Quick guide - Trichoderma. Magazine Current Biology, 20:390-391, 2010.

CARDOSO, S. C.; BARBOSA-MENDES, J. M.; BOSCARIOL, R. L.; CHRISTIANO, R. S. C.; BERGAMIN FILHO, A.; VIEIRA, M. L. C.; MENDES, B. M. J.; MOURÃO FILHO, F. A. A. Transgenic sweet orange (Citrus sinensis L. Osbeck) expressing the attacin $A$ gene for resistance to Xanthomonas citri subsp. citri. Plant Molecular Biology Reporter, 28:185-192, 2010.

CARMONA, M. J.; MOLINA, A.; FERNANDEZ, J. A.; LÓPEZ-FANDO, J. GARCÍA-OLMEDO, F. Expression of the $\alpha$-thionin gene from barley in tobacco confers enhanced resistance to bacterial pathogens. The Plant Journal, 3(3):457-462, 1993.

CARPENTER, M. A.; STEWART, A.; HIDGWAY, H. J. Identification of novel Trichoderma hamatum genes expressed during mycoparasitism using subtractive hybridisation. FEMS Microbiology Letters, 251:105-112, 2005

CEASAR, S.A; IGNACIMUTHU, S. Genetic engineering of crop plants for fungal resistance role of antifungal genes. Biotechnology letters, 34:995-1002, 2012.

CUNHA, W.G.; TINOCO, M. L.P.; PANCOTI, H. L.; RIBEIRO, R. E.; ARAGÃO, F.J.L. High resistance to Sclerotinia sclerotiorum in transgenic soybean plants transformed to Express na oxalate decarboxylase gene. Plant pathology, 2010.

DANA, M. M, PINTOR-TORO, J.A. CUBERO, B. Transgenic tobacco plants overexpressing quitinases of fungal origin show enhanced resistance to biotic and abiotic stress agents. Plant Physiology. 142:722-730, 2006.

DIAS-LOPES, C.; NESHICH, I. A. P.; NESHICH, G.; ORTEGA1, J. M.; GRANIER, C.; CHÁVEZ-OLORTEGUI1, C.; MOLINA, F.; FELICORI1, L. Identification of New Sphingomyelinases D in Pathogenic Fungi and Other Pathogenic Organisms. FEBS Letters, 584:1887-1894, 2010.

DICKSON, R. New insights into sphingolipid metabolism and function in budding yeast. Journal of Lipid Research, 49: 909-921, 2008. 
DRUZHININA, I. S.; SEIDL-SEIBOTH.; HERRERA-ESTRELA, A. HORWITZ, B. A.; KENERLEY, C. M.; MONTE, E.; MUKHERJEE, P. K.; ZEILINGER, S.; GRIGORIEV, I.; KUBICEK, C. P. Trichoderma: the genomics of opportunistic success. Nature reviews: microbiology, 9, 2011.

FUKUTA, S.; KAWAMOTO, K. MIZUKAMI, Y.; YOSHIMURA, Y. UEDA, J. KANBE, M. Transgenic tobacco plants expressing antimicrobial peptide bovine lactoferricin show enhanced to phytopathogens. Plant biotechnology, 29:383-389, 2012.

GER, M.; CHEN, C.; HWANG, S. HUANG, H. PODILE, A. R. DAYAKAR, B. V. FENG, T. Constitutive expression of hrap gene in transgenic tobacco plant enhances resistance against virulent bacterial pathogens by induction of a hypersensitive response. Molecular Plant-Microbe Interactions. 15(8):764-773, 2002.

GONI, F.M.; ALONSO, A. Sphingomyelinases: enzymology and membrane activity. FEBS letters, 531(1):38-46, 2002.

GASSMÉ, H.; BECKER, K. A. Bacterial infections and ceramide. Handbook Experimental Pharmacology, 216:305-20, 2013.

GROVER, A.; GOWTHAMAN, R. Strategies for development of fungus-resistanc transgenic plants. Current Science,84(3)330-340, 2003.

HERMOSA, M. R.; GROMDONA, I.; ITURRIAGA, A.; DIAZ-MINGEZ, J. M.; CASTRO, C.; MONTE, E.; CARCIA-ACHA, I. Molecular characterization and identification of Biocontrol isolates of Trichoderma spp. Applied and environmental microbiology, 1890-1898, 2000.

HERMOSA, R.; VITERBO, A.; CHET, I.; MONTE, E. Plant-beneficial effects of Trichoderma and of its genes. Microbiology, 158:17-25, 2012.

HIGHTOWER, R.; BADEN, C.; PENZES, E.; DUNSMUIR, P. The expression of cecropin peptide in transgenic tobacco does not confer resistance to Pseudomonas syringae pv. tabaci, Plant Cell Reports, 13:295-299, 1994.

HIROOKA, T.; ISHII, H. Chemical control of plant diseases. Journal of General Plant Pathology, 79:390-401, 2013.

HOWELL, C. R. Mechanisms Employed by Trichoderma Species in the Biological Control of plant disease: The history and evolution of current concepts. Plant Disease $87: 1-7,2003$

HUANG, Y.; NORDEEN, O. R.; DI, M.; OWENS, L. D.; MCBEATH, J. H. Expression of an engineered Cecropin gene cassette in transgenic tobacco plants confers disease resistance to Pseudomonas syringae pv. tabaci. Molecular Plant Pathology, 87(5): 494-499, 1997 
HYAKUMACHI, M. Research on biological control of plant diseases: present state and perspectives. Journal General. Plant Pathology. 79:435-440, 2013.

JAYNES, J, M.; NAGPALA, P.; DESTÉFANO-BELTRAN, L.; HUANG, J. H.; KIM, J.; DENNY, T.; CETINER, S. Expression of a cecropin B lytic peptide analog in transgenic tobacco confers enhanced resistance to bacterial wilt caused by Pseudomonas solanacearum, Plant Science, 89:43-53, 1993.

KADO, C.I.; HESKETT, M.G. Selective media for isolation of Agrobacterium, Corynebacterium, Erwinia, Pseudomonas and Xanthomonas. Phytopathology, 60: 969976, 1970.

KING, M. THE MEDICAL BIOCHEMISTRY PAGE. Introduction to the NiemannPick Diseases, available online. Disponível em http://themedicalbiochemistrypage.org/niemannpickdiseases.php, acesso em 15/03/2014.

KLEIN, D.; EVELEIGH, D. E. Ecology of Trichoderma In: KUBICEK, C. P.; HARMAN, G. E. Trichoderma and Gliocladium: Basic biology, taxonomy and genetics, Taylor and Francis London, 57-69, 1998.

KIRK, P. Index Fungorum. CABI Bioscience, CBS and landcare Research, avaliable online, ed. 2014. Disponível em http://www.indexfungorum.org, acesso em 08/01/2014.

KUBICEK, C. P. HERRERA-ESTRELLA, A.; SEIDL-SEIBOTH, V.; MARTINEZ, D. A. DRUZHININA, I. S.; THON, M.; ZEILINGER, S.; CASAS-FLORES, S.; HORWITZ, B. A.; MUKHERJEE, P. K.; MUKHERJEE, M.; KREDICS, L.; ALCARAZ, L. D.; AERTS, A.; ANTAL, Z.; ATANASOVA, L.; CERVANTESBADILLO, M. G.; CHALLACOMBE, J.; CHERTKOV, O.; MCCLUSKEY, K.; COULPIER, F.; DESHPANDE, N.; DÖHREN, H. V.; EBBOLE, D. V.; ESQUIVELNARANJO, E. U.;FEKETE, E.; FLIPPHI, M.; GLASER, F.;ÓMEZ-RODRÍGUEZ, E.; GRUBER, S.; HAN, C.; HENRISSAT, B.; HERMOSA, R.; HERNÁNDEZ-OÑATE, M.; KARAFFA, L.; KOSTI, I.; CROM, S. L.; LINDQUIST, E.; LUCAS, S.; LÜBECK, M.;LÜBECK, P.S.; MARGEOT, A.;METZ, B.;MISRA, M.; NEVALAINEN, H.; OMANN, M.; PACKER, N.; PERRONE, G.; URESTI-RIVERA, E.; SALAMOV, A.; SCHMOLL, M.; SEIBOTH, B.;SHAPIRO, H.;SUKNO, S.; TAMAYO-RAMOS, J. A.; TISCH, D.; WIEST, A.;WILKINSON, H. H.; ZHANG, M.; COUTINHO, P. C.; KENERLEY, C. M. MONTE, E.; BAKER, S. E.; GRIGORIEV I. V. Comparative genome sequence analysis underscores mycoparasitism as the ancestral life style of Trichoderma. Genome Biology,12, 2011.

KHALILUEV, M. R.; SHPAKOVSKII, G.V. Genteic engineering strategies for enhancing Tomato to fungal and bacterial pathogens. Russian Journal of Plant Physiology, 60:721-732, 2013.

KUMAR, V.; PARKHI, V.; KENERLEY, C. M.; RATHORE, K. S. Defense related gene expression and enzyme activities in transgenic cotton plants expressing an 
endoquitinase gene from Trichoderma virens in response to interaction with Rhizoctonia solani. Planta, 230:277-291, 2009.

ISLAM, A. Fungus resistant transgenic plants: strategies, progress and lessons learnt. Plant Tissue Culture and Biotechnology, 16 (2): 117-138, 2006

LACORTE, C.; ROMANO, E. Transferência de Vetores para Agrobacterium. In: BRASILEIRO, A. C. M, CARNEIRO, V. T. C. Manual de Transformação Genética de Plantas. Embrapa, Brasília. 51-64. 1998.

LI, Q.; LANKEN, C.V.; YANG,J.;LAWRENCE, C. B.; HUNT, A.G. The yeast polyadenylate-binding (PAB1) gene acts as disease lesion mimic gene when expressed in plants. Plant Molecular Biology, 42:335-344,2000.

LIU, P.G., YANG, Q. Identification of genes with a biocontrol function in Trichoderma harzianum mycelium using the expressed sequence tag approach. Research Microbiology, 156(3):416-423,2005.

LIU, M., SUN, Z. X., ZHU, J., XU, T., HARMAN, G. E., LORITO, M. Enhancing rice resistance to fungal pathogens by transformation with cell wall degrading enzyme genes from Trichoderma atroviride. Journal Zhejiang University Science, 5:133-136, 2004.

LORITO, M.; WOO, S. L.; FERNANDEZ, I. G. COLUCCI, G.; HARMAN, G. E.; PINTOR-TORO, J. A. FILLIPPONE, E. MUCCIFORA, S.; LAWRENCE, C. B.; ZOINA, A.; TUZUN, S.; SCALA, F. Genes from mycoparasitic fungi as a source for improving plant resistance fo fungal pathogens. Proceedings of the National Academy of Sciences, 95:7860-7865, 1998

LORITO, M.; WOO, S. L.; HARMAN, G. E.; MONTE, E.; Translational research on Trichoderma: from omics to the field. Annual review of phytopathology, 48: 395-417, 2010.

LUKYANOV, S. A.; REBRIKOV, D.; BUZDIN, A. A. Supression Subtrative Hybridization. In: LUKYANOV, S. A.; BUZDIN, A. A. Nucleic Acids Hybridization, Springer, 53-84, 2007.

MACEYKA, M.; PAYNE, S.G.; MILSTIEN, S. AND SPIEGEL, S. Sphingosine kinase, sphingosine-1-phosphate, and apoptosis Biochimica et Biophysica Acta, 1585:193-201,2002.

MASSART, S.; JIJAKLI, H. M.; Use of molecular techniques to elucidate the mechanisms of action of fungal biocontrol agents: A review. Journal of Microbiological Methods, 69:229-241, 2007.

MILHAS, D.; CLARKE, C. J.; HANNUN, Y. A. Sphingomyelin metabolism at the plasma membrane: implications for bioactive sphingolipds. FEBS Letters, 584:18871894, 2010. 
MILLER, J. H. Experiments in molecular genetics. New York: Cold Spring Harbor; 1972.

MOHAN S,K.; SCHAAD, N.W. Semi selective agar media forisolating Pseudomonas syringae pv. syringae and Pseudomonassyringae pv. phaseolicola from bean seed. Phytopathology, 77:1390-1395, 1987.

MONTERO-BARRIENTOS, M.; HERMOSA, R.; CARDOZA, R. E.; GUTIÉRREZ, S.; NICOLA' S, C.; MONTE, E. Transgenic expression of the Trichoderma harzianum hsp70 gene increases Arabidopsis resistance to heat and other abiotic stresses. Journal Plant Physiology, 167:659-665, 2010.

MURASHIGE, T.; SKOOG, E.A. Revised medium for rapid growth and bioassays with tobacco tissue cultures. Physiology Plant. 15: 473-497, 1962.

NELSON, D. L.; COX, M. M. Princípios de bioquímica de Lehninger. 5 ed. Porto Alegre: Artmed, 2011

NICOLÁS, C.; HERMOSA, R.; RUBIO, B.; MUKHERJEE, P. K.; MONTE, E. Trichoderma genes in plants for stress tolerance-status and prospects. Plant Science: 228:17-78, 2014.

OBEID, L. M.; OKAMOTO, Y.; MAO, C. Sphingolipds: metabolism and biology. Biochimica et Biophysica Acta,1585:163- 171,2002.

ODUM, E. P. Ecologia. São Paulo: Pioneira, 1986.

OSLEN, I.; JANTZEN, E. Sphingolipids in bactéria and fungi. Anaerobe, 07:103-112, 2001.

OSUSKY, M.; ZHOU, G.; OSUSKA, L.; HANCOCK, R. E.; KAY, W. W.; MISRA, S. Transgenic plants expressing cationic peptide chimeras exhibit broad-spectrum resistance to phytopathogens. Nature biotechnology, 18: 1162-1166, 2000.

PAOLI, L. G.; BOSCARIOL-CAMARGO, R. L.; HARAKAVA, R. MENDES, B. M. J.; MOURÃO FILHO, F.A.A. Transformação genética de laranja 'Valência' com o gene cecropin MB39. Pesquisa Agropecuária Brasileira, 42 (11):1663-1666, 2007.

REBRIKOV, D. V.; DESAI, S. M.; SIEBERT, P. D.; LUKYANOV, S. A.; Suppression subctrative hybridization. Methods in Molecular Biology, 258, 2008

RECH, E L.; ARAGÃO, F. J. L. Biobalística. In: BRASILEIRO, A. C. M, CARNEIRO, V. T. C. Manual de Transformação Genética de Plantas. Embrapa, Brasília. 51-64. 1999.

ROMANO, E. Extração de DNA de tecidos vegetais In: BRASILEIRO, A. C. M, CARNEIRO, V. T. C. Manual de Transformação Genética de Plantas. Embrapa, Brasília. 51-64. 1998b. 
RUSTAGI, A.; KUMAR, D.; SHEKHAR, S.; YUSUF, M. A.; MISRA, S. SARIN, N. B. Transgenic Brassica juncea plants expressing MsrA1, a cationic antmicrobial peptide, exhibit resistance to phytopathogens. Molecular Biotechnology, 56:535-545, 2014.

SAMOLSKI, I.; LUIS, A.; VIZCAÍNO, J. A.; MONTE, E. SUÁREZ, M. B. Gene expression analysis of the biocontrol fungus Trichoderma harzianum in the presence of tomato plants, chitin, or glucose using a high-density oligonucleotide microarray BMC Microbiology, 9:217, 2009

SCHERM, B., SCHMOLL, M., BALMAS, V., KUBICEK, C.P., MIGHELI, C. Identifcation of potential marker genes for Trichoderma harzianum strains with high antagonistic potential against Rhizoctonia solani by a rapid subtraction hybridization approach. Current Genetics, 55(1):81-91, 2008.

SCHUSTER, A. SCHMOLL, M. Biology and biotechnology of Trichoderma. Applied Microbiology Biotechnology, 87: 787-799, 2010.

SHAH, J. M., RAGHUPATHY, V. \& VELUTHAMBI, K. Enhanced sheath blight resistance in transgenic rice expressing an endoquitinase gene from Trichoderma virens. Biotechnology Letters, 31:239-244, 2009.

SHAH, M. R. MUKHERJEE, P. K. EAPEN, S. Expression of a fungal endochitinase gene in transgenic tomato and tobacco results in enhanced tolerance to fungal pathogens. Physiol. Mol. Biol. Plants., 16(1): 39-51, 2010.

SILVEIRA, J. R. P.; DUARTE. V.D.; MORAES. M. G. Ocorrencia das biovares 1 e 2 de Ralstonia solanacearum em lavouras de batata no estado do Rio Grande do Sul. Fitopatologia Brasileira, 27(5): 450-453, 2002.

SIMS, K. J.; SPASSIEVA, S. D.; VOIT, E. O.; OBEID, L. M. Yeast sphingolipd metabolism: clues and connections. Biochem Cell Biol. 82(1):45-61, 2004

SAMBROOK, J., RUSSEL, D.W. Molecular Cloning: A laboratory manual. 3rd ed. Cold Spring Harbor Laboratory Press, Cold Spring Harbor, New York. 2001

SINGH, D.; AMBROISE, A.; HAICOUR, R.; SIHACHAKR, D.; RAJAM, M. V. Increased resistance to fungal wilts in transgenic eggplant expressing alfalfa glucanase gene. Physiology Molecular Biology Plants, 20(2):143-150, 2014.

SUÁREZ, B.; REY M.; CASTILlO, P.; MONTE, E. LOBELL, A. Isolation and characterization of PRA1, a trypsin-like protease from the biocontrol agent Trichoderma harzianum CECT 2413 displaying nematicidal activity. Applied Microbiology Biotechnology 65:46-55, 2004

STEFANOVA, M.; SALA, P. I. A. L.; DAMASCENO, J. P. S.; MARQUES, A. S. A. Optimization de la recuperación de Pseudomonas syringae pv. tabaci por la 
modificación de lós médios de cultivo. Tropical Plant Pathology, 34(3):178-181, 2009.

STEINDORFF, A. S.; SILVA, R. N.; COELHO, A. S. G.; NAGATA, T.; NORONHA, E. F.; ULHOA, C.J. Trichoderma harzianum expressed sequence tags for identification of genes with putative roles in mycoparasitism against Fusarium solani. Biological Control. 2012.

THEVISSEN, K.; FERKET, K. K. A.; FRANÇOIS, I. E. J. A.; CAMMUE, B. P. A. Interactions of antifungal plant defensins with fungal membrane components. Peptídes, 24: 1705-1712, 2003.

TROIAN, R. F.; STEINDROFF, A. S.; RAMADA, M. H. S.; ARRUDA, W.; ULHOA, C. J. Mycoparasitism studies of Trichoderma harzianum against Sclerotinia sclerotiourm: evaluition of antagonism and expression of cell wall degrading enzymes genes. Biotechnology Letters, 36(10): 2095-2101, 2014.

VIEIRA, P. M. COELHO, A. S. G. STEINDORFF, A. S. SIQUEIRA, S. J. L.; SILVA, R. DO N.; ULHOA, C. J. Identification of differentially expressed genes from Trichoderma harzianum during growth on cell wall of Fusarium solani as a tool for biotechnological application. BMC Genomics, 14:177, 2013.

WALLY, O.; PUNJA, Z.K. Genetic engineering for increasing fungal and bacterial disease resistance in crop plants. GM Crops, 1(4):199-206, 2010.

VINALE, F. SIVASITHAMPARAM, K.; GHISALBERTIC, E. L.;MARRA, R.; WOO, S. L.; LORITO, M. Trichoderma plant pathogen interactions. Soil Biology \& Biochemistry, 40:1-10, 2008.

VIZCAINO, J. A.; GONZALEZ, F.J.; SUAREZ, M. B.; REDONDO, J.; HEINRICH, J. Generation, annotation and analysis of ESTs from Trichoderma harzianum CECT 2413. BMC Genomics, 7:193, 2006

VIZCAINO, J. A.; REDONDO, J.; SUAREZ, M. B.; CARDOZA, R. E.; HERMOSA, R. Generation, annotation, and analysis of ESTs from four different Trichoderma strains grown under conditions related to biocontrol. Applied Microbiology Biotechnology, $75: 853-62,2007$.

ZASLOFF, M. Antimicrobial peptides of multicellular organisms. Nature 415:389-395 2002.

YU, HONG.; ZEIDAN, Y. H.; WU, B. X.; JENKINS, R.W. FLOTTE, T. R. HANNUN, Y. A. VIRELLA-LOWELL, I. Defective acid sphingolyelinase pathway with Pseudomonas aeruginosa infection in cystic fibrosis. American Journal of Respiratory cell and molecular biology, 41:367-375, 2009 